\title{
Role of the Tian Shan Mountains and Pamir Plateau in Increasing Spatiotemporal Differentiation of Precipitation over Interior Asia
}

\author{
Yingying Sha, ${ }^{\mathrm{a}}$ ZHengGuo ShI, ${ }^{\mathrm{a}, \mathrm{b}, \mathrm{c}}$ XIAODONG LiU,,${ }^{\mathrm{a}, \mathrm{b}}$ ZHISHENG AN, \\ XINZHOU LI, ${ }^{\text {a,b }}$ AND HONG CHANG ${ }^{a}$ \\ ${ }^{a}$ State Key Laboratory of Loess and Quaternary Geology, Institute of Earth Environment, \\ Chinese Academy of Sciences, Xi'an, China \\ ${ }^{\mathrm{b}}$ CAS Center for Excellence in Tibetan Plateau Earth Sciences, Beijing, China \\ ${ }^{\mathrm{c}}$ Open Studio for Oceanic-Continental Climate and Environment Changes, Pilot National \\ Laboratory for Marine Science and Technology (Qingdao), Qingdao, China
}

(Manuscript received 6 September 2017, in final form 26 June 2018)

\begin{abstract}
Numerical simulations were conducted to determine the impact of the Tian Shan Mountains and Pamir Plateau on arid conditions over interior Asia. These topographies are crucial for the differentiation of the precipitation seasonality among the subregions in the west, east, and north of the Tian Shan Mountains and Pamir Plateau, namely, arid central Asia, the Tarim basin, and the northern plains. Before the uplift of the Tian Shan Mountains and Pamir Plateau, the precipitation seasonality over the east arid subregion was consistent with that over the west arid subregion, with maximum rainfall in spring and winter and minimum rainfall in summer. After the uplift of the Tian Shan Mountains and Pamir Plateau, the original precipitation seasonality in the west was strengthened. As the precipitation in the east arid subregion increased in summer but decreased in winter and spring, the precipitation seasonality in the east changed to peak in summer, while the precipitation in the north arid subregion showed the opposite change. The precipitation alteration corresponded well with the change of vertical motion. With the modulation of atmospheric stationary waves, the remote East Asian monsoon was also impacted. Though enhanced southerly wind blew over East Asia, the monsoon precipitation over the east coast of China and subtropical western Pacific Ocean was significantly reduced as an anticyclonic circulation appeared. The Tian Shan Mountains and Pamir Plateau also contributed to the intensification of the East Asian winter monsoon.
\end{abstract}

\section{Introduction}

The eolian dust deposited on the Chinese Loess Plateau and in the Pacific Ocean has shown past changes in Asian winter monsoon, midlatitude westerlies, and Asian inland desertification (Liu 1985; An et al. 1991; Rea et al. 1998; Ding et al. 1999). With the long and continuous eolian deposition, the onset of aridification of inland Asia dates back to the late Oligocene to early Miocene (Guo et al. 2002; Sun et al. 2010; Qiang et al. 2011). Geological records and numerical simulations have demonstrated that the aridification of the Asian interior is closely connected to the uplift of the Tibetan Plateau (Kutzbach et al. 1989; Broccoli and Manabe 1992; Rea et al. 1998; An et al. 2001; Guo et al. 2008; Molnar et al. 2010; Shi et al. 2011; Liu and Dong 2013). Based on combining the records of eolian deposition

\footnotetext{
Corresponding author: Yingying Sha, shayingying@ieecas.cn
}

with evidence of the growth of the Tibetan Plateau, An et al. (2006) suggested four major stages of the strengthening of Asian inland aridification during 25-22, 16-14, 10-7, and 4-2.6 Ma, which are related to the stepwise uplift and expansion of the Tibetan Plateau. The Tibetan Plateau is a huge heat source in summer (Ye and Gao 1979; Yanai and Li 1994), which generates ascending motion over its area and causes the surrounding air to converge toward it (Wu et al. 2007). This circulation is associated with subsiding air across the west and north of the Tibetan Plateau, which suppresses precipitation over these regions. The topography also acts as a mechanical barrier to prevent moist southerly air from being transported to the continental interior. In winter, large stationary waves occur in response to the Tibetan topography. The arid Asian interior is located upstream of the wave trough, where subsidence occurs, thus reducing precipitation (Broccoli and Manabe 1992; Kutzbach et al. 1993; Sato 2009). 
Arid interior Asia is geographically divided into the west and east parts by the wetter Tian Shan Mountains and Pamir Plateau. The west subregion mainly comprises Uzbekistan, Turkmenistan, and other countries located to the west of Tian Shan Mountains and Pamir Plateau, which can be simply described as typical arid central Asia. The eastern dry lands cover northwestern China, including the world's second-largest shifting sand desert, the Taklimakan Desert, and southern Mongolia. In addition to the separation of geographic position in arid interior Asia, the seasonal cycle of precipitation is opposite between the west and east arid subregions. The precipitation in the west falls primarily in winter and spring, with much less precipitation in summer (Aizen et al. 2001; Lioubimtseva et al. 2005; Schiemann et al. 2008; Huang et al. 2013; Yin et al. 2014). The winter precipitation results from the eastward propagation of midlatitude cyclones from the Mediterranean Sea and dominant moisture transport by westerlies (Aizen et al. 2001; Martyn 1992; Syed et al. 2006; Schiemann et al. 2008; Chen et al. 2010; Bothe et al. 2012; Caves et al. 2015). In summer, the strong surface heating leads to the formation of thermal lows and associated clear and dry conditions. Periodic intrusions of cooler air masses from the north, northwest, or west are also accompanied by dry and rather clear conditions over the deserts (Aizen et al. 2001; Schiemann et al. 2008).

The east arid subregion is characterized by maximum precipitation in summer and minimum rainfall in winter (Yu et al. 2001; Sato et al. 2007; Zhu et al. 2015; Baldwin and Vecchi 2016), which is consistent with the temporal variation in the regions controlled by the Asian summer monsoon. The monsoon-like seasonal cycle and geographical location suggest that the arid east subregion is under the influence of the Asian monsoon, with moist air masses brought by southerly flows in summer. Yatagai and Yasunari (1998) showed that daily heavy precipitation over the Taklimakan Desert is related to southerly flows across the Tibetan Plateau, but this mainly occurs in wet years and only appeared in up to $10 \%$ of total cases. Because of the blocking of the Tibetan Plateau and the Qinling and Qilian Mountains, the Indian and East Asian summer monsoon cannot reach arid northwestern China (Huang and Chen 2010); as one ancient Chinese poem entitled "Liangzhou word" by Huanzhi Wang in the Tang Dynasty says, "Beyond the Jade Gate vernal wind will never blow." Some studies have indicated that the moisture supply contributing to precipitation over the east arid subregion is mainly provided by midlatitude westerlies (Tian et al. 2001; Dirmeyer and Brubaker 2007; Sato et al. 2007; Huang and Chen 2010; Bothe et al. 2012).

Besides the observed opposite seasonality between the west and east, the precipitation north of the Tian
Shan Mountains (referred to as north subregion) presents a different pattern, with maximal rains in spring and autumn but minimal in summer. Observed monthly mean precipitation over the arid west, east, and north subregions in interior Asia were averaged to specify the precipitation seasonality (Fig. 1a). The specific subregions mainly cover typical central Asia, the Tarim basin, and north of the Tian Shan Mountains (Fig. 1b). Figure 1a clearly shows the different seasonality among the three subregions.

A recent pedogenic carbonate oxygen record from terrestrial sediments shows carbonate $\delta^{18} \mathrm{O}$ values exhibited a robust $4 \%$ decrease over eastern Kazakhstan in the late Neogene, which sharply contrasts with nearly all records from downwind localities in interior China and Mongolia (Caves et al. 2017). The author indicated that the $\delta^{18} \mathrm{O}$ decreases were caused by the uplift of the Tian Shan and Altai Mountains, which induced a shift of precipitation seasonality over the windward region toward dominant spring and autumn precipitation. This suggests that the different precipitation seasonality among the arid west, east, and north subregions is related to the effect of the adjacent mountain ranges. However, most modeling studies have treated the arid Asian interior as a whole, so the different precipitation seasonality among the arid west, east, and north subregions and its relationship with topography remain unsolved. With the Tian Shan Mountains and Pamir Plateau as a natural blocking dividing the three subregions, it is necessary to identify their influence on the aridification and precipitation seasonality of arid interior Asia and distinguish their role from the main body of the Tibetan Plateau.

With a $2500-\mathrm{km}$ east-west trending range and the summits higher than $7000 \mathrm{~m}$, the Tian Shan Mountains and Pamir Plateau dominate the central Asian landscape (Fig. 1b; Charreau et al. 2009). The Tian Shan Mountains and Pamir Plateau have risen to their present-day height since $\sim 15-10 \mathrm{Ma}$, so this area is much younger that the main Tibetan Plateau (Rowley and Currie 2006; Charreau et al. 2009; Molnar et al. 2010). The major growth even occurred late in the Pliocene (Zheng et al. 2000; Sun et al. 2004; De Grave et al. 2007; Sobel et al. 2011). The paleoclimatic records indicate the progressive aridification of inland Asia since $\sim 10 \mathrm{Ma}$ is associated with the topography located at the northern margin of the main Tibetan Plateau (Chang et al. 2012; Liu et al. 2014; Sun et al. 2015). The relationship between the smaller mountain ranges and climate has been emphasized in a few numerical simulations with high horizontal resolution (Sato 2005; Liu et al. 2015; Shi et al. 2015; Sha et al. 2015; Baldwin and Vecchi 2016; Shi et al. 2017). Besides the 
a) Observation

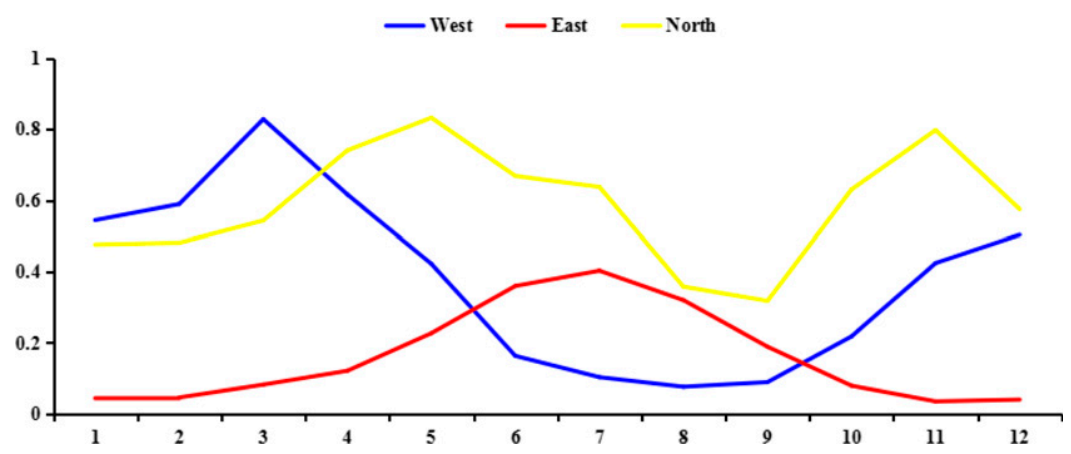

b) Sub-regions

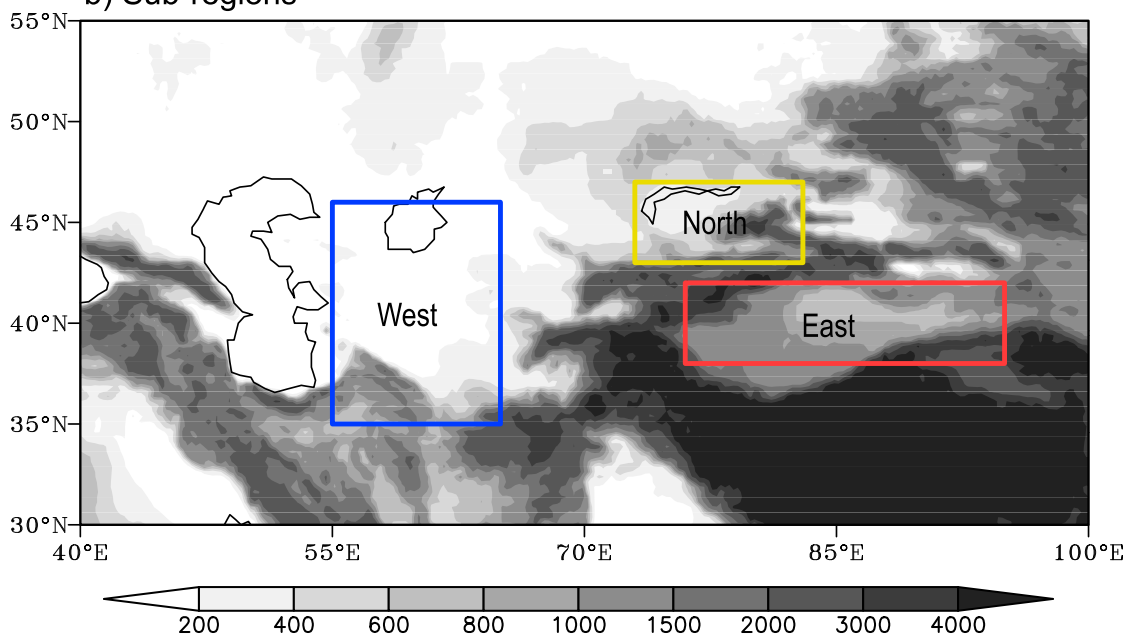

FIG. 1. (a) Seasonal cycles of precipitation $\left(\mathrm{mm} \mathrm{day}^{-1}\right)$ derived from the APHRODITE dataset. The blue, red, and yellow lines represent the monthly mean precipitation in the arid west, east, and north subregions of the Tian Shan Mountains and Pamir Plateau, respectively. Precipitation is averaged only at altitudes below $1200 \mathrm{~m}$. (b) Boxes show the three arid subregions examined in the study, mainly including arid central Asia $\left(35^{\circ}-46^{\circ} \mathrm{N}, 55^{\circ}-65^{\circ} \mathrm{E}\right)$, the Tarim basin $\left(38^{\circ}-42^{\circ} \mathrm{N}, 76^{\circ}-95^{\circ} \mathrm{E}\right.$, ), and the plains north of the Tian Shan Mountains $\left(43^{\circ}-\right.$ $47^{\circ} \mathrm{N}, 73^{\circ}-83^{\circ} \mathrm{E}$,). Shaded is the ETOP05 topography (m).

simulated rain shadow effect of the Tian Shan Mountains and other topographies north of the Tibetan Plateau (Sato 2005; Liu et al. 2015), the smaller mountain ranges also have remote influence on Asian monsoons and the westerly jet (Shi et al. 2015; Sha et al. 2015; Zhang et al. 2015; Baldwin and Vecchi 2016; Shi et al. 2017). For example, the Mongolian Plateau significantly strengthens the East Asian winter monsoon and westerly jet over Japan (Shi et al. 2015; Sha et al. 2015). Baldwin and Vecchi (2016), indicating that the East Asia summer monsoon can also be enhanced by the uplift of the Tian Shan Mountains.

The numerical simulations related to the Tian Shan Mountains presented inconsistent precipitation changes over interior Asia (Sato 2005; Baldwin and Vecchi 2016). In summer, the precipitation in the upwind region, which represent the areas in the northwest portion of the Tian Shan Mountains, was enhanced with the uplift of the Tian Shan Mountains (Sato 2005). There was little effect on the amount of precipitation over the Tarim basin in the south of the Tian Shan Mountains. However, Baldwin and Vecchi (2016) showed the Tian Shan Mountains induced an increase of summer precipitation in the Tarim basin, while a decrease in the upwind region. They indicated that the summer increase was related to the local orographic effects, as significant easterly moisture fluxes reach the Tian Shan Mountains. Besides the inconsistency, the abovementioned seasonality shift over eastern Kazakhstan also remains unexamined by numerical simulations. Thus, the changes of precipitation and its seasonality over the arid interior Asia need further detailed numerical simulation. To 
examine the impact of the Tian Shan Mountains and Pamir Plateau on the differentiation of the precipitation seasonality over arid interior Asia, we conducted three model experiments by utilizing the National Center for Atmospheric Research (NCAR) Community Atmosphere Model, version 4.0 (CAM4.0), with a high horizontal resolution of $0.47^{\circ} \times 0.63^{\circ}$ (latitude $\times$ longitude).

Following this introduction, a brief description of the observational data and experimental design is given in section 2. The arid conditions, precipitation amounts, and seasonality over arid interior Asia is then analyzed in section 3. Section 4 is an exploration of the accompanying circulation and thermal structure changes. The numerical simulation results are summarized and discussed in section 5 .

\section{Data and model experiments}

A daily gridded precipitation dataset created by the Asian Precipitation-Highly Resolved Observational Data Integration Toward Evaluation of Water Resources (APHRODITE) product was used to evaluate the precipitation seasonality of the Asian interior. The APHRODITE products contain substantial rain gauge data and use an interpolation method that considers orographic effects (Yatagai et al. 2014). We used version V1101 with $0.25^{\circ}$ resolution and covering the time period from 1951 to 2007. It contains three subregions: the Asian monsoon region $\left(0^{\circ}-55^{\circ} \mathrm{N}, 60^{\circ}-155^{\circ} \mathrm{E}\right)$, parts of Russia $\left(34^{\circ}-84^{\circ} \mathrm{N}, 15^{\circ} \mathrm{E}-165^{\circ} \mathrm{W}\right)$, and the Middle East $\left(25^{\circ}-45^{\circ} \mathrm{N}, 15^{\circ}-65^{\circ} \mathrm{E}\right)$. To fully cover interior Asia, we merged the three subdatasets together and formulated monthly precipitation.

The "with" and "without" mountain simulations were performed with CAM4.0. CAM4.0 is characterized by a default finite-volume dynamical core and a modified Zhang and McFarlane (1995) deep convection parameterization, which significantly improves the capability to simulate the phase, amplitude, and spatial anomaly patterns of El Niño (Neale et al. 2010). With higher horizontal resolution in CAM4.0, the improvements of the simulation appear primarily where topographic effects may be playing a role, including a substantially improved simulation of precipitation associated with the Indian summer monsoon (Bacmeister et al. 2014). In this study, a relatively high horizontal resolution of $0.47^{\circ} \times$ $0.63^{\circ}$ was used to present the complex and small-scale topography of the Tian Shan Mountains and Pamir Plateau.

Three numerical simulations under different topographic boundaries were conducted to distinguish the role of the Tian Shan Mountains and Pamir Plateau and the main body of the Tibetan Plateau in the aridification of the Asian interior, especially the different precipitation seasonality. The first was the control run with modern topography (Control). The Tian Shan Mountains and Pamir Plateau were removed in the second run (mvTS-Pr). The third run removed the main Tibetan Plateau (mvTP). The topographies of the three runs are presented in Fig. 2. As the Tarim basin is the main component of the east arid subregion, the altitude of the Tarim basin did not change in all three experiments. Because of the relatively high altitude of the Tarim basin (about $1000 \mathrm{~m}$ ), the height of the Tian Shan MountainsPamir Plateau and the Tibetan Plateau removed in the mvTS-Pr and mvTP runs were reduced to $1200 \mathrm{~m}$, respectively. The constant and unaltered topography of the Tarim basin in the three experiments avoided climate changes induced by the topographical uplift of the Tarim basin itself. In the study, we only changed the altitude of the topographies; other boundary conditions were kept the same in the three runs, with greenhouse gases set to preindustrial values. Each experiment was integrated for 20 years and the last 15 years were used for analysis.

\section{Precipitation patterns}

\section{a. Observed precipitation}

Based on annual mean precipitation from the APHRODITE dataset averaged from 1979 to 2007, the arid regions, including the subtropical latitudes between $15^{\circ}$ and $35^{\circ} \mathrm{N}$ and the arid Asian interior, were all characterized by an annual precipitation rate of less than $1 \mathrm{~mm} \mathrm{day}^{-1}$ (Fig. 3a). The $1 \mathrm{~mm} \mathrm{day}^{-1}$ contour line also separated arid interior Asia into the west and east parts, with the wetter mountainous area of the Tian Shan Mountains-Pamir Plateau between them. The east arid land received much less rain than the west. The annual precipitation rate over arid central Asia and the Tarim basin was 0.381 and $0.162 \mathrm{~mm} \mathrm{day}^{-1}$, respectively. To distinguish the distinctly different precipitation seasonality between the arid west and east subregions, a simple index $S_{p}$ was created. It refers to the difference in the precipitation rate between winter and summer (DJF minus JJA). Thus, areas with $S_{p}$ greater than 0 represent areas in which precipitation was dominant in winter, whereas values below 0 indicate regions in which more rainfall occurred in summer than in winter. The greater the absolute value of $S_{p}$, the more pronounced the precipitation seasonality.

The dotted areas in Fig. 3b illustrate where precipitation in winter was higher than in summer. The winter dominant regions were located over the west of the Tian Shan Mountains-Pamir Plateau, stretching 

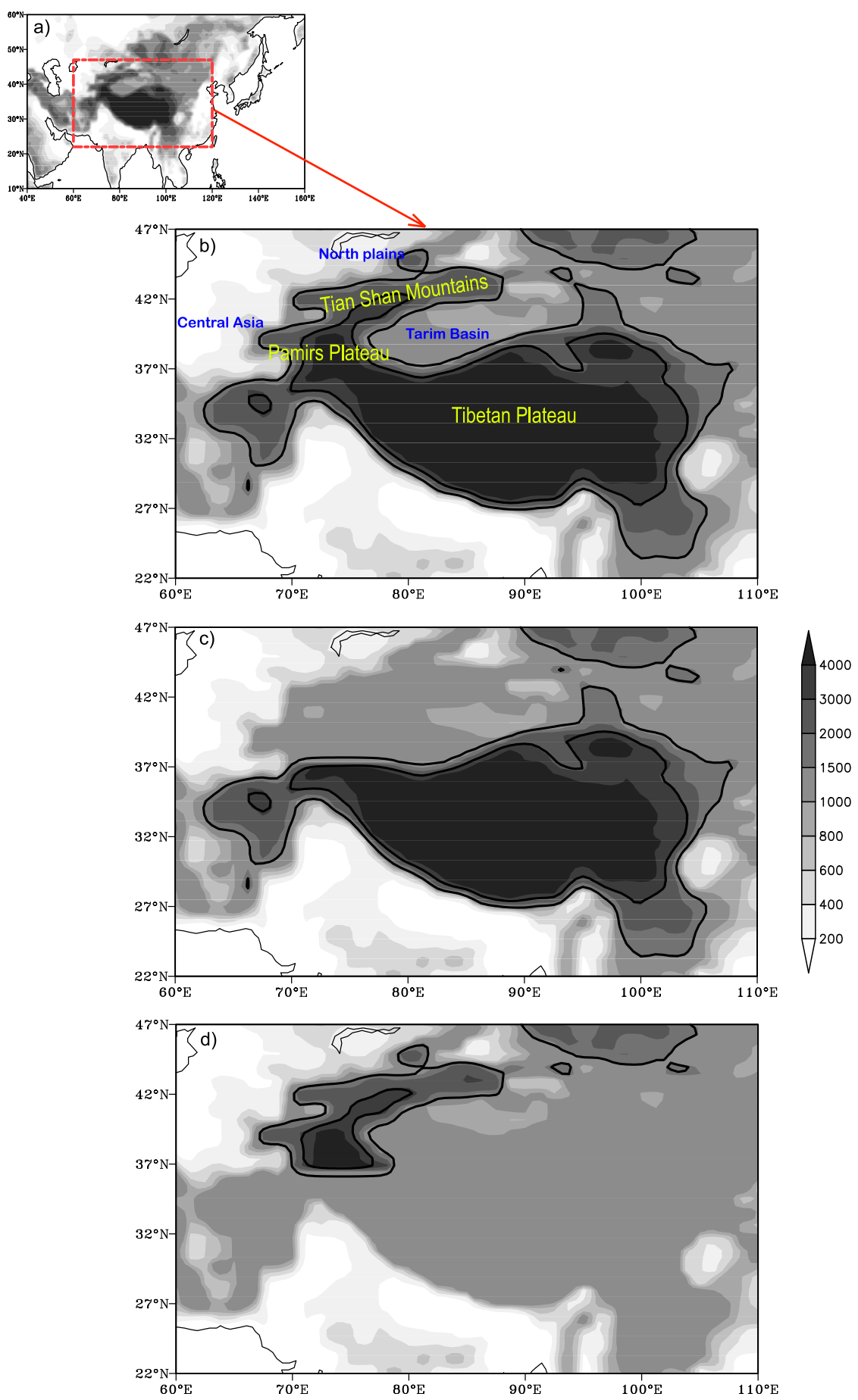

FIG. 2. Elevation (m) in the three experiments: (a),(b) Control run; (c) mvTS-Pr run; (d) mvTP run. The black contours show the altitude lines of 1500 and $3000 \mathrm{~m}$.

approximately from $20^{\circ}$ to $55^{\circ} \mathrm{N}$. This area mainly includes central Asia, the Arabian Peninsula, and the Mediterranean. The maximum difference was in central Asia between $30^{\circ}$ and $40^{\circ} \mathrm{N}$. The negative $S_{p}$ covered a vast landmass east of approximately $75^{\circ} \mathrm{E}$, including the east arid subregions and Asian monsoon-controlled regions. The decrease of negative $S_{p}$ from northwest to southeast showed the enhancement of summerdominant precipitation seasonality. Thus, the $S_{p}$ index is appropriate for quantitatively describing the distinct 
a) Annual

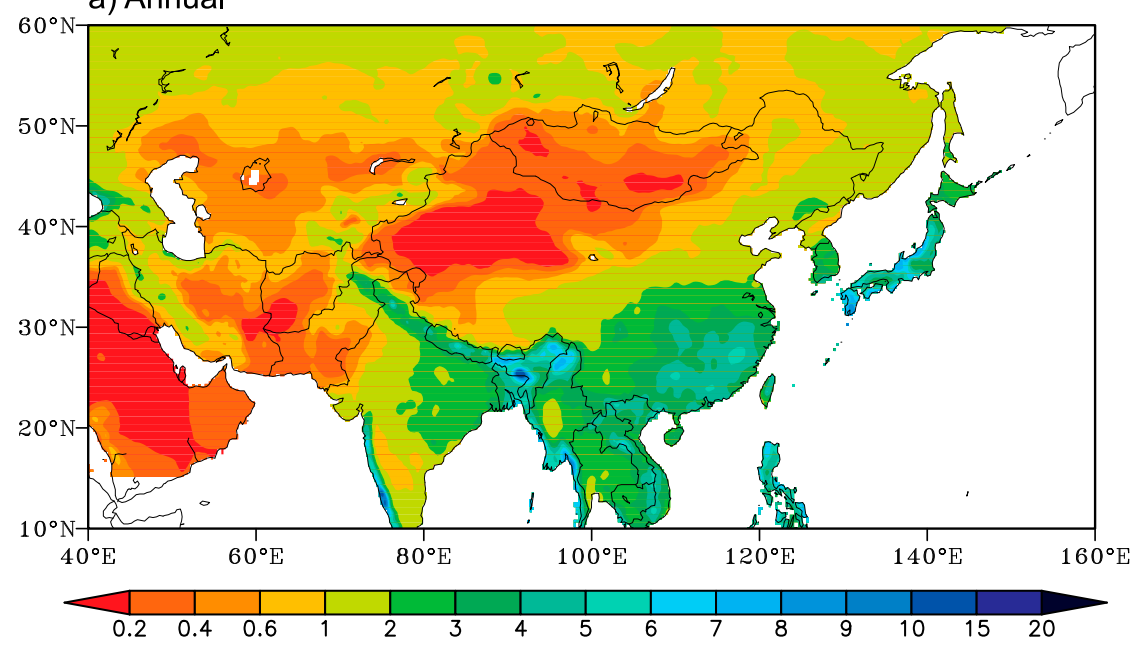

b) DJF-JJA

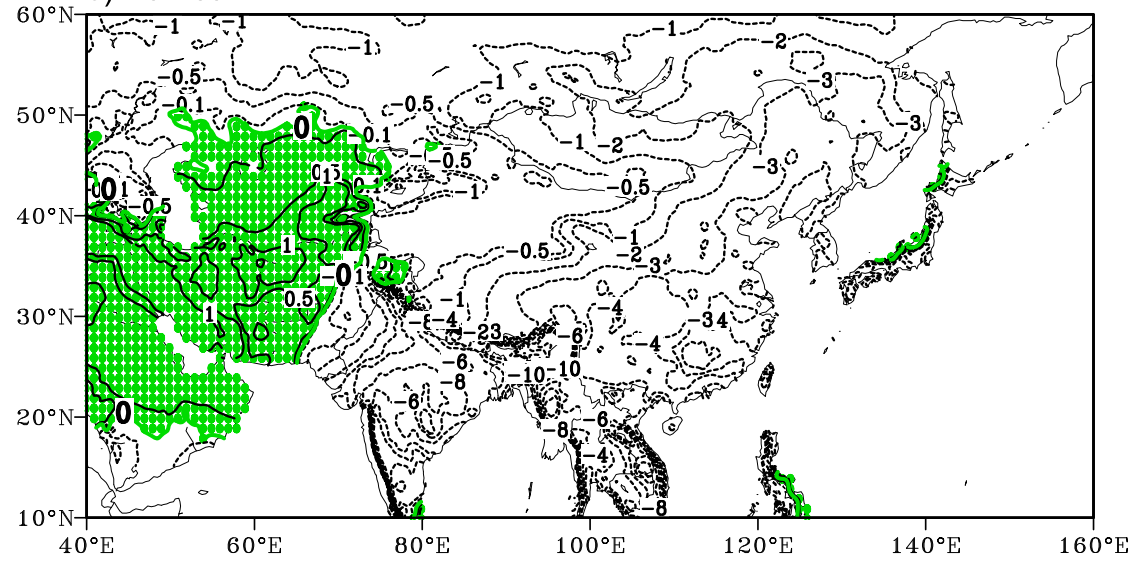

FIG. 3. (a) Annual mean precipitation $\left(\mathrm{mm} \mathrm{day}^{-1}\right)$ derived from the APHRODITE dataset. (b) Observed winter-dominant precipitation regions (green dots). The black contours show the precipitation difference between summer (JJA) and winter (DJF).

opposite precipitation seasonality between the west arid subregion and the east arid subregion.

\section{b. Modeled precipitation}

The annual precipitation in the Control run showed a similar distribution pattern to the observations (Figs. 4a and 3a). The maximum rainfall occurred over regions controlled by the Asian summer monsoon, whereas minimum precipitation occurred in arid interior Asia. Over East Asia, precipitation decreased gradually from the southeastern coast toward northwestern inland China. Notably, the high-resolution CAM4.0 captured the maximum precipitation centers over South Asian monsoon regions, such as the western Indian Peninsula and southern foothills of the Himalaya. Compared with the observations (Fig. 3a), the arid subtropical region (represented by precipitation rate below $1 \mathrm{~mm} \mathrm{day}^{-1}$ ) located beneath the subsidence branch of the Hadley cell was dismissed in the Control run (Fig. 4a). The midlatitude arid region retreated southward from $55^{\circ}$ to $50^{\circ} \mathrm{N}$ and westward from $125^{\circ}$ to $120^{\circ} \mathrm{E}$. However, the west arid subregion and east arid subregion of interior Asia were clearly distinguishable from the wetter Tian Shan Mountains and Pamir Plateau. Besides, the modeled annual precipitation in the east arid subregion was lower than in the west arid subregion, which was also consistent with the APHRODITE dataset. Thus, the numerical simulations conducted by CAM4.0 captured the precipitation patterns over arid interior Asia well, with only some quantitative bias.

In the mvTS-Pr run, the annual precipitation pattern was distinctly changed over arid interior Asia (Fig. 4b). The arid lands were no longer separated into the west and east subregions, but were transformed and connected as one large arid area. A different aridity pattern was also 


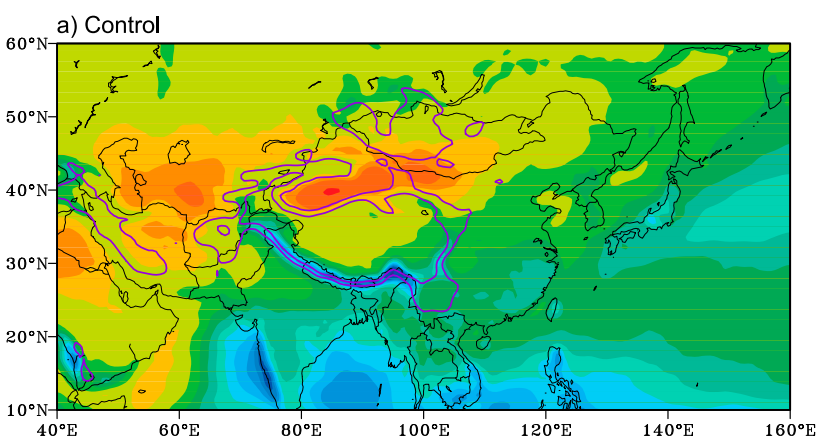

b) mvTS-Pr

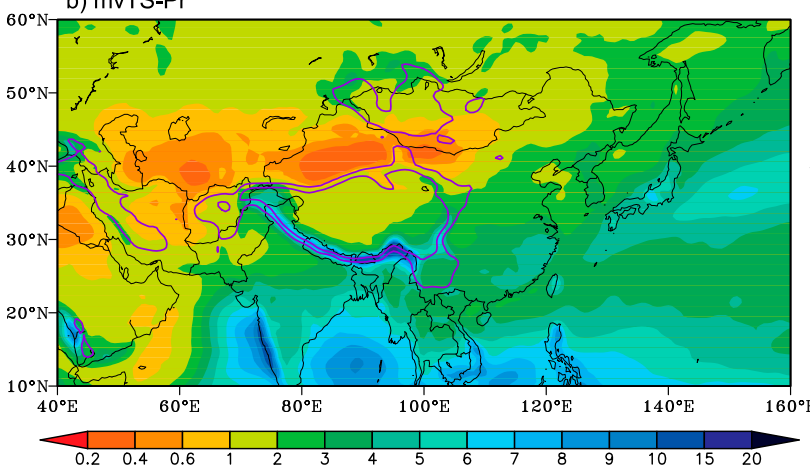

c) mvTP

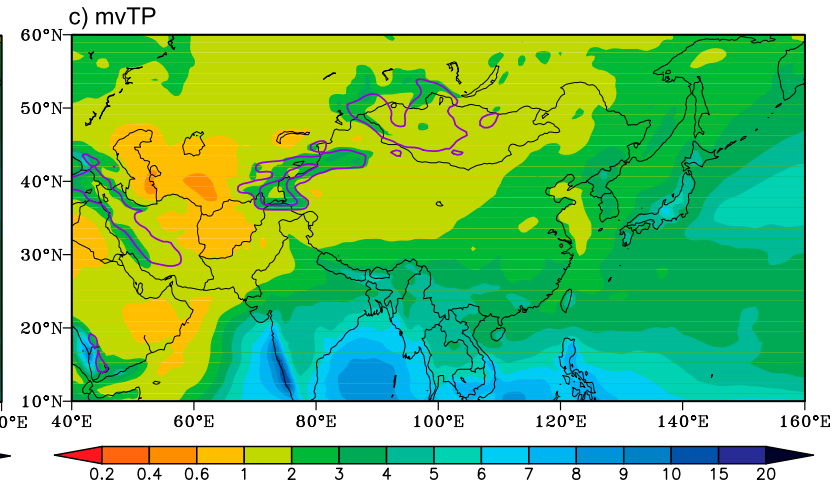

FIG. 4. Annual mean precipitation ( $\mathrm{mm} \mathrm{day}^{-1}$; shaded) in the three experiments: (a) Control run, (b) mvTS-Pr run, and (c) mvTP run. The purple contours show the altitude lines of 1500 and $3000 \mathrm{~m}$.

revealed in the mvTP run (Fig. 4c). Without the main Tibetan Plateau, the arid region still appeared over central Asia, but disappeared over the east subregion including northwestern China and southern Mongolia. The difference between the Control and mvTP runs shows the climate effect of the main Tibetan Plateau uplift (Fig. 5a), whereas the difference between the Control and mvTS-Pr runs illustrates the role of the Tian Shan Mountains and Pamir Plateau (Fig. 5b). With the uplift of the main Tibetan Plateau, the annual precipitation was significantly increased over the Asian summer monsoon-controlled region, especially in the foothills of the Himalaya (Fig. 5a). Consistent decrease was over the vast regions west and north of the Tibetan Plateau, including the arid subtropics, the entire interior Asia, and northeastern Asia. The change of annual precipitation induced by the Tian Shan Mountains and Pamir Plateau was different from the main Tibetan Plateau (cf. Figs. 5b and 5a). It was significantly intensified over the uplifted ranges (Fig. 5b). Remarkable decrease occurred in the arid east and north subregions, whereas the precipitation change in the west arid subregion was not significant. The different response of annual precipitation indicates that the Tian Shan Mountains and Pamir Plateau were essential for the division of arid subregions between the west and the east.

The precipitation and its associated $850-\mathrm{hPa}$ circulation in summer and winter were specified (Fig. 6). In summer, a strong anticyclone occupied the entire central Asia (Fig. 6a). It stretched southward to $30^{\circ} \mathrm{N}$ and northward to $50^{\circ} \mathrm{N}$. Its center was located between the Caspian and Aral Seas, at approximately $45^{\circ} \mathrm{N}$. The west arid subregion was thus under the control of northerly wind. The westerly wind, which was pushed and extended to higher latitudes above $55^{\circ} \mathrm{N}$, flowed eastward and entered into the passage between the Tian Shan Mountains and the Mongolian Plateau in a southeastward direction. The northwesterly wind was then divided into two branches. One branch turned into the Tarim basin, resulting in strong easterly wind. The other branch continued moving eastward and flowed through the regions between the Mongolian Plateau and the Tibetan Plateau. The precipitation pattern of the interior Asia in summer resembles the annual mean pattern (Fig. 3a), as the wetter Tian Shan Mountains and Pamir Plateau separated the arid land into the west and east parts. The west arid part was restricted to the latitudes above $30^{\circ}$ and $50^{\circ} \mathrm{N}$, which were under the control of the anticyclone. The east arid part covered the basins adjacent to the Tibetan Plateau, Tian Shan Mountains and Pamir Plateau, and Mongolian Plateau. The west arid subregion was much drier than the east arid subregion.

Compared with the precipitation rate in summer (Fig. 6a), the winter $1 \mathrm{~mm} \mathrm{day}^{-1}$ contour line in the west of the topographies moved southward to lower latitudes 
a) TP ANN

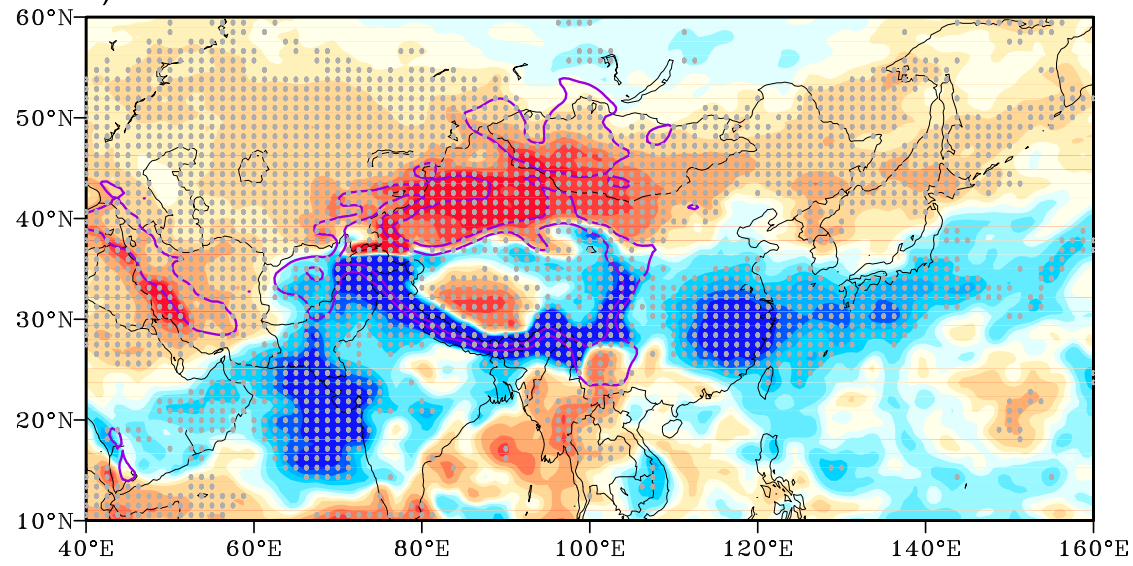

b) TS-Pr ANN

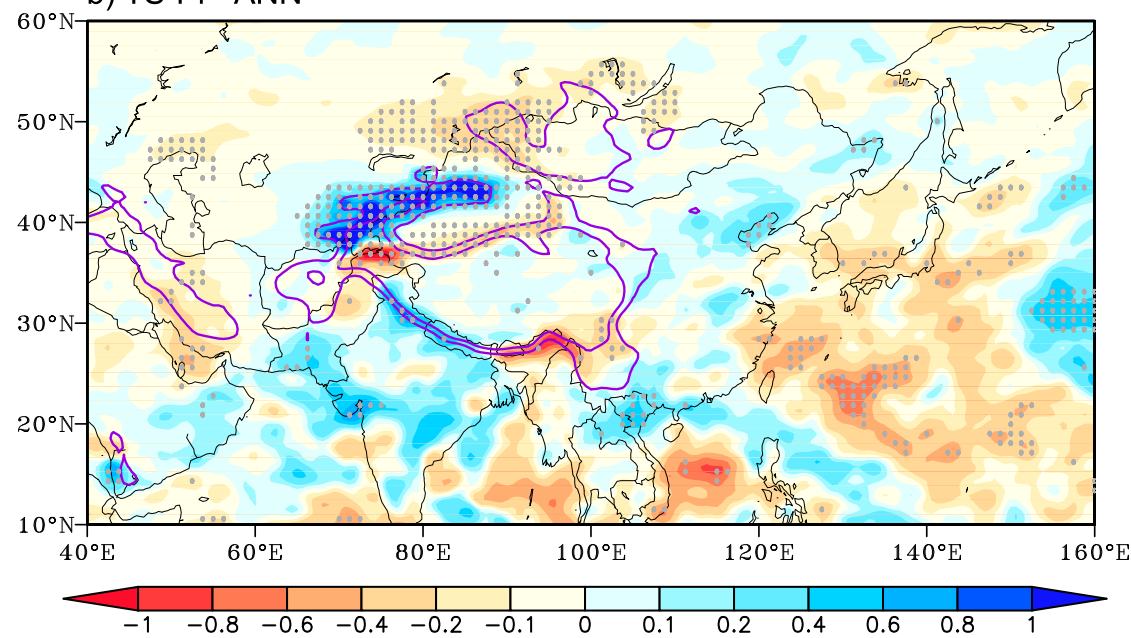

FIG. 5. Change in annual mean precipitation ( $\mathrm{mm} \mathrm{day}^{-1}$; shaded): (a) anomaly induced by the Tibetan Plateau (Control minus mvTP) and (b) anomaly induced by the Tian Shan Mountains and Pamir Plateau (Control minus mvTS-Pr). The dotted areas indicate where the difference was significant at the $95 \%$ confidence level, based on a two-tailed Student's $t$ test. The purple contours show the altitude lines of 1500 and $3000 \mathrm{~m}$.

(Fig. 6d). Therefore, severe aridity took place in the subtropics, whereas the west arid subregion could receive more rains in winter than in summer. The winter $1 \mathrm{~mm} \mathrm{day}^{-1}$ contour line in the east of the Tian Shan Mountains and Pamir Plateau encompassed a much larger region than in summer. It expanded both southward and northward and also extended eastward to $135^{\circ} \mathrm{E}$. The east arid subregion was drier than the west arid subregion in winter, which was opposite to the summer conditions (cf. Figs. 6b and 6a). During winter, the anticyclone in the west of the mountain ranges moved to the lower latitudes south of $30^{\circ} \mathrm{N}$ and thus suppressed the precipitation in these regions. The midlatitude westerly wind strengthened and expanded southward to $30^{\circ} \mathrm{N}$. When the strong westerlies blocked by the Tian Shan Mountains and Pamir Plateau (Fig. 6b), it bypassed along the west boundary of the mountain ranges and turned to a northeastward direction, and thus the west arid subregion was characterized by southwesterly wind. The east dry lands were also under the influence of westerlies, but their intensity was weaker than that in the west subregion. Besides, an anticyclone was formed in the Tarim basin, which favored the divergence of airflows. The different arid conditions between the arid subregion and east arid subregion suggest that the spatial distribution of the seasonal precipitation in interior Asia is closely related to the intensity and location of the westerlies and the anticyclone.

With the uplift of the main body of the Tibetan Plateau, the precipitation over interior Asia was consistently reduced both in summer and winter (Figs. 6b,e). During summer, a significant easterly wind anomaly 

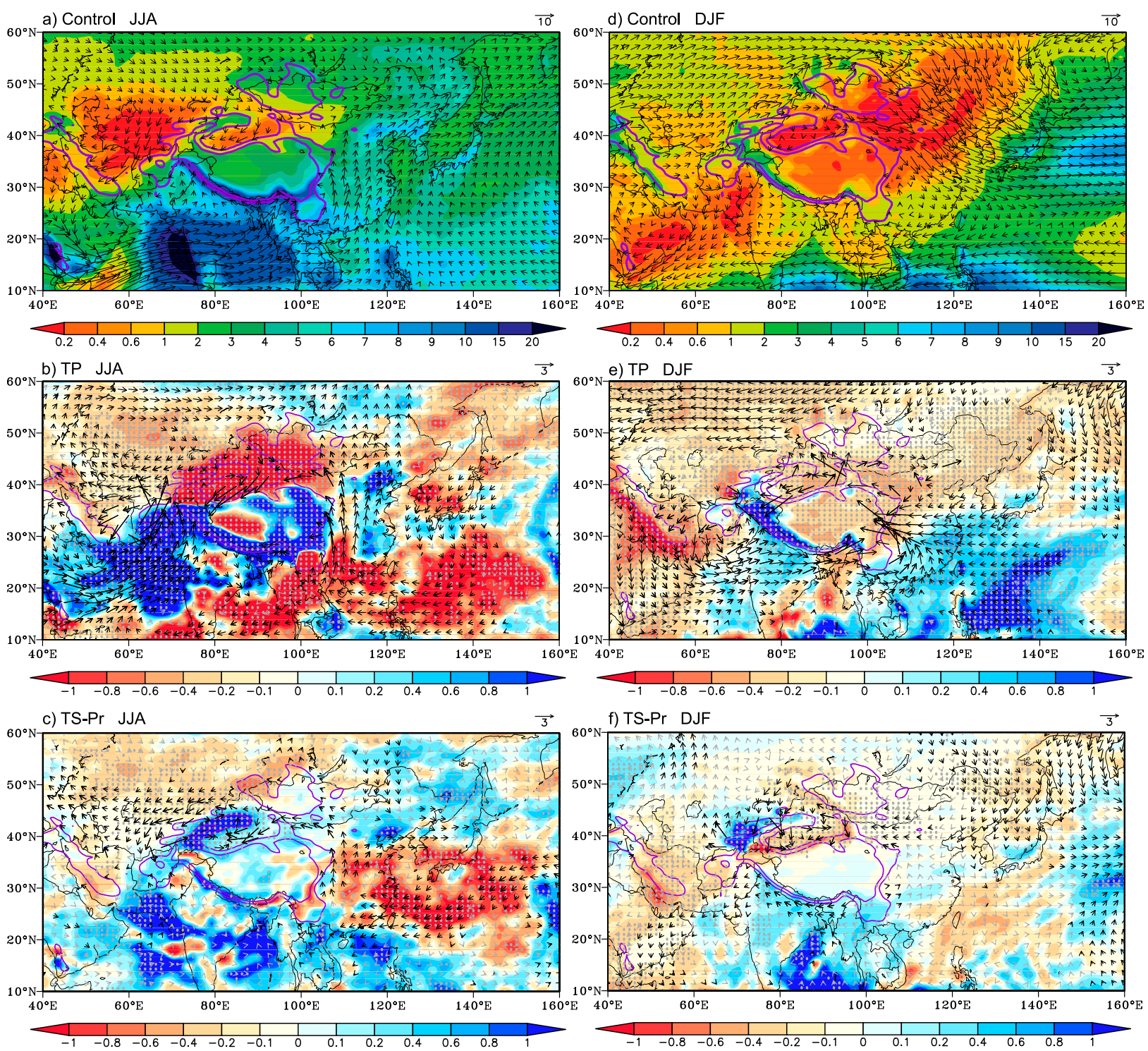

FIG. 6. Change in precipitation $\left(\mathrm{mm} \mathrm{day}^{-1}\right)$ and $850-\mathrm{hPa}$ wind vectors $\left(\mathrm{m} \mathrm{s}^{-1}\right)$ in summer and winter: (a) summer mean in the Control run, (b) anomaly induced by the Tibetan Plateau in summer, and (c) anomaly induced by the Tian Shan Mountains and Pamir Plateau in summer. (d)-(f) As in (a)-(c), respectively, but for the mean state and anomaly in winter. The wind vectors in black and dotted areas indicate where the difference was significant at the $95 \%$ confidence level, based on a two-tailed Student's $t$ test. The purple contours show the altitude lines of 1500 and $3000 \mathrm{~m}$.

appeared in the west and north of the Tibetan Plateau (Fig. 6b). The anticyclone located in central Asia was also intensified. The East Asian summer monsoon was strengthened with the significant intensification of southerly wind and precipitation. After the uplift of the Tian Shan Mountains and Pamir Plateau (Fig. 6c), precipitation in the arid west and north subregions reduced with strong easterly wind anomaly. However, significant increase of precipitation occurred over the uplifted ranges and the east arid subregion. These regions were also characterized by intensified easterly wind. In terms of the East Asian summer monsoon, the southerly wind strengthened over eastern China. However, precipitation over east China, southern Japan, and the northwest Pacific Ocean was consistently reduced, as an anticyclonic anomaly appeared and anchored over the eastern coast.

During winter, westerly wind throughout the midlatitude Eurasian continent weakened with the uplift of the Tibetan Plateau (Fig. 6e). With the anomalous easterly and northerly wind, precipitation in the whole midlatitudes was significantly reduced. With the uplift of the Tian Shan Mountains and Pamir Plateau, a coherent reduction of 


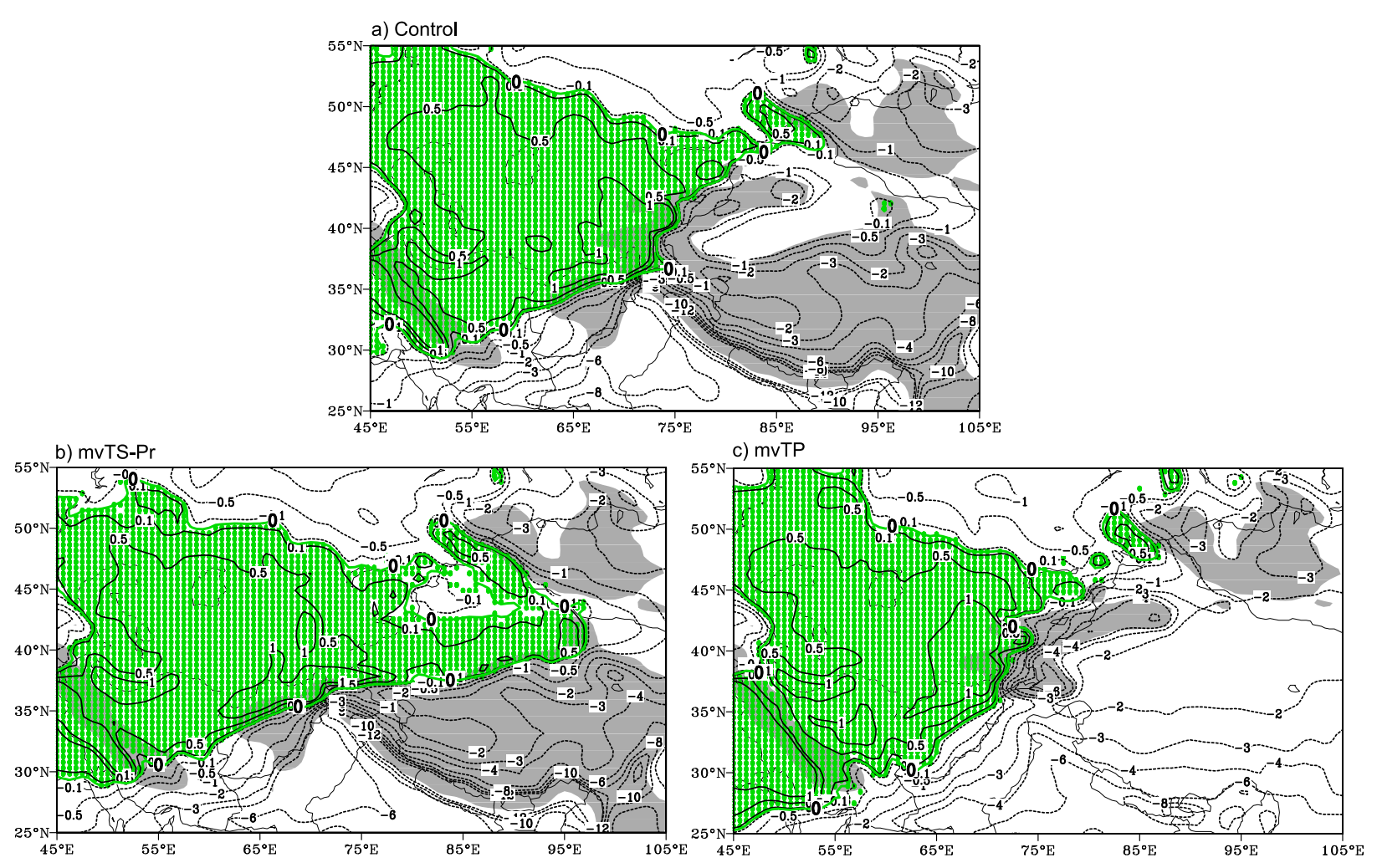

FIG. 7. Winter-dominant precipitation regions (green dots) in the three experiments: (a) Control run, (b) mvTS-Pr run, and (c) mvTP run. The black contours show the precipitation difference between summer and winter. The areas higher than $1500 \mathrm{~m}$ are shaded in gray.

precipitation occurred over the west and east arid subregions (Fig. 6f). In contrast, precipitation increased over the uplifted mountains and the north subregion. The East Asian winter monsoon was also intensified. The significant strengthening of the northerly wind and the reduction of precipitation appeared in northeastern China. In general, unlike the Tibetan Plateau-induced consistent decrease of precipitation over interior Asia (Figs. 6b,e), the Tian Shan Mountains and Pamir Plateau-caused precipitation alteration varied among the arid west, east, and north subregions (Figs. 6c,f). With the uplift of the Tian Shan Mountains-Pamir Plateau, the arid east subregion was characterized by higher rainfall in summer while the precipitation in the north subregion increased in winter.

According to the different seasonality of precipitation over arid interior Asia, we used the $S_{p}$ index to indicate the effect of the topographies on determining the dominant precipitation season (Fig. 7). Compared with the observed distribution of $S_{p}$ (Fig. 3b), the positive $S_{p}$ extended slightly eastward and retreated northward in the Control run (Fig. 7a). Apart from the biases, the $S_{p}$-revealed seasonality boundary fitted well with the observations. In the mvTS-Pr run, the regions with winter-dominant precipitation extended eastward to $95^{\circ} \mathrm{E}$ (Fig. $7 \mathrm{~b}$ ). The east arid subregion became a region with more rains in winter than in summer, which was coherent with the west arid subregion. The $S_{p}$ index in the mvTP run showed a similar distribution to the Control run (cf. Figs. 7a and 7c); namely, the precipitation seasonality pattern over arid interior Asia was not influenced by the uplift of the main Tibetan Plateau. Therefore, the transformation and differentiation of precipitation seasonality between the arid west and east subregions only formed with the uplift of the Tian Shan Mountains and Pamir Plateau (cf. Figs. 7a and 7b).

The simulated monthly mean precipitation over the arid west, east, and north subregions is shown in Fig. 8. In the three simulations, the west arid subregion kept consistent precipitation seasonality, with most rainfall in spring and winter and lowest rainfall in summer (Fig. 8a). Precipitation in the mvTP run was substantially higher throughout the entire year than that in the Control and mvTS-Pr runs. The difference between the Control and mvTP runs showed a consistent decrease of monthly mean precipitation (Fig. 8a). The precipitation anomaly induced by the Tian Shan Mountains and Pamir Plateau varied between months. It decreased in summer and early autumn from June to September but increased in other months, especially in spring. In the Control and mvTP runs, the east arid subregion was characterized by 
a) West

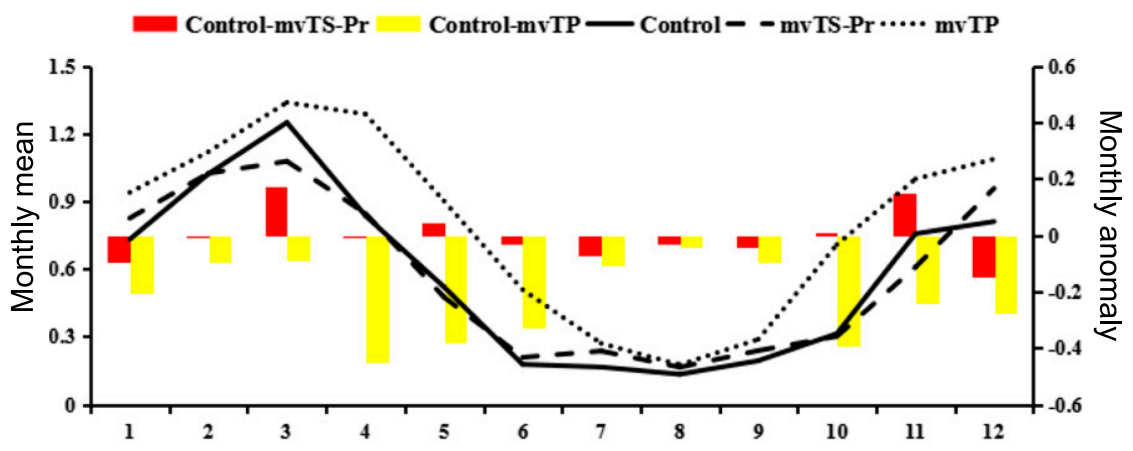

b) East

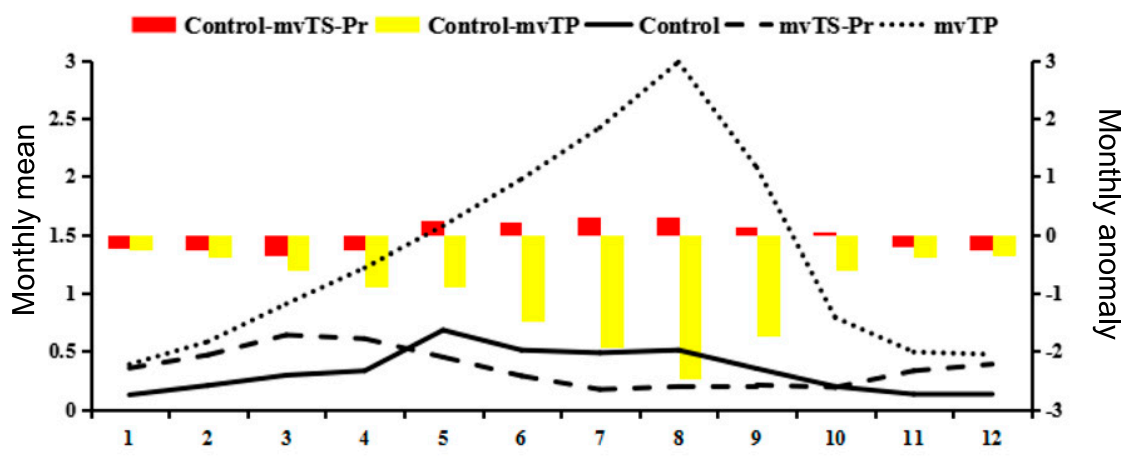

c) North

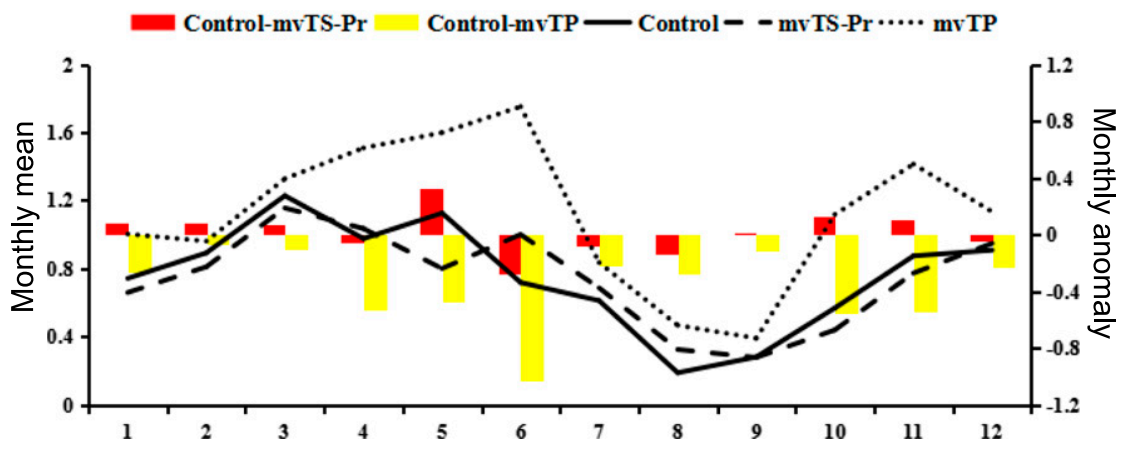

FIG. 8. Change in seasonal cycles of precipitation averaged in the arid subregions of (a) west, (b) east, and (c) north. The lines indicate the monthly mean precipitation in the Control (solid line), mvTS-Pr (dashed line), and mvTP (dotted line) runs. The bars are the precipitation anomalies induced by the Tian Shan Mountains and Pamir Plateau (red bars) and by the Tibetan Plateau (yellow bars).

maximum precipitation in summer and minimum in winter (Fig. 8b). In the mvTS-Pr run, the annual cycle was opposite to that in the Control and mvTP runs, as more rains fell in winter and spring than in summer. Compared with the consistent decrease of precipitation in each month induced by the main Tibetan Plateau, the precipitation from May to October was intensified by the uplift of the Tian
Shan Mountains and Pamir Plateau-caused increases in summer. Over the north arid subregion, the Control run captured the observed characteristic that the precipitation rates in both autumn and spring were both higher than in summer (Fig. 8c). In the mvTP and mvTS-Pr runs, the dominant rainfall still occurred in spring, but the driest season changed to autumn. Similar to the changes in 
monthly mean precipitation over the arid west and east subregions (Figs. 8a,b), the precipitation over the north subregion also showed a significant decrease throughout the whole year with the uplift of the main Tibetan Plateau (Fig. 8c). However, more rains fell in autumn, winter, and spring with the uplift of the Tian Shan and Pamir Plateau. Precipitation decrease only appeared in summer.

Therefore, the Tibetan Plateau mainly induced a consistent decrease in monthly mean precipitation over the three arid subregions, but the effect of the Tian Shan Mountains and Pamir Plateau varied. More importantly, it changed the precipitation seasonality in the east arid subregion by inducing more rainfall in summer and less rainfall in winter. Compared with the east subregion, the north subregion exhibited a nearly opposite change, in which the precipitation decreased in summer but increased in winter, spring, and autumn.

\section{Atmospheric circulation changes}

The following sections focus on the horizontal water vapor transport, vertical motion, and stationary waves in summer and winter to analyze the possible mechanisms related to the precipitation changes.

\section{a. Water vapor transport}

The climatological mean water vapor in arid interior Asia was transported by predominant midlatitude westerlies (Figs. 9a,d). During summer, central Asia was characterized by an intense anticyclone in the lower troposphere (Figs. 6a and 9a). Therefore, the westerly wind in summer was restricted to higher latitudes than that in winter. The moist air brought by westerlies then split into two branches. One branch turned southward and joined the northerly wind in the east of the anticyclone, bringing moisture to the west arid subregion. The other branch continually moved eastward and brought moisture to eastern interior Asia. Though the climatological mean state indicated a dominant easterly moisture transport in the east arid subregion, the lower-level water vapor flux and wind flow suggested that the easterly moisture transport was more likely to occur through the bypassing flows induced by midlatitude westerlies rather than moist easterlies coming from the East Asian summer monsoon (Figs. 6a and 9a). The southeasterly water vapor transport induced by the East Asian summer monsoon was restricted to the east of $100^{\circ} \mathrm{E}$ and could not pass the high topography. The difference in water vapor flux between the Control and mvTP runs showed significant easterly moisture transport anomalies across the west arid subregion (Fig. 9b). This indicates that the uplift of the Tibetan Plateau induced a large decrease in the eastward transport of water vapor to interior Asia. In contrast, the southerly water vapor transport intensified over the East Asian summer monsoon-controlled regions. With the uplift of the Tian Shan Mountains and Pamir Plateau, significant anomalous easterly water vapor transport appeared in arid interior Asia (Fig. 9c). Compared with the effect of the Tibetan Plateau (Fig. 9b), southerly moisture flux anomalies also appeared over the region controlled by the East Asian monsoon. However, an anticyclonic anomaly was anchored in the east coast of China, which suppressed the East Asian summer monsoon precipitation (Fig. 6c).

Under the seasonal movement of maximum solar radiation, the westerly moisture flux expanded far southward to $30^{\circ} \mathrm{N}$ in winter (Fig. 9d). With the split of westerlies at approximately $35^{\circ} \mathrm{N}$, southwesterly wind of the split northern branch brought moist air to the west arid subregion (Fig. 9d), which was opposite to the northwesterly moisture transport in summer (Fig. 9a). Moreover, the east arid subregion, where water vapor was transported by strong easterlies in summer, was characterized by relatively weak westerly moisture flux in winter. Southeastward transport of water vapor occurred over regions controlled by the East Asian winter monsoon. Figure 9e shows consistent easterly moisture flux anomalies across arid interior Asia and East Asia. With the uplift of the Tian Shan Mountains and Pamir Plateau, the arid west subregion was characterized by intensified southerly moisture transport (Fig. 9f). Anomalous moisture flux divergence appeared in the east arid subregion. The intensified lower-level divergence contributed to the decrease of the precipitation in this region (Figs. 6f and 7c).

\section{b. Vertical motion}

The effect of topography on aridification in interior Asia can also be examined by the alteration of vertical motion. Because of the different changes in precipitation among the arid west, east, and north subregions, the latitude-height cross sections of vertical motion over these three subregions were analyzed (Figs. 10-12). In summer, consistent subsidence and northerly wind prevailed throughout the west arid subregion (Fig. 10a). With the southward movement of maximum solar radiation in winter, the subsiding branch of the Hadley circulation moved to the latitudes south of $35^{\circ} \mathrm{N}$. Instead of descending motion, the west arid subregion was characterized by ascending motion in winter (Fig. 10d). Besides, the lower-level meridional wind changed to southerlies, which was opposite to the northerlies in summer. The seasonal alteration of meridional circulation was closely related to the intensity of precipitation. In response to dry northerly winds and dominant descending motion in summer, the precipitation over the west arid subregion was suppressed. During winter, 

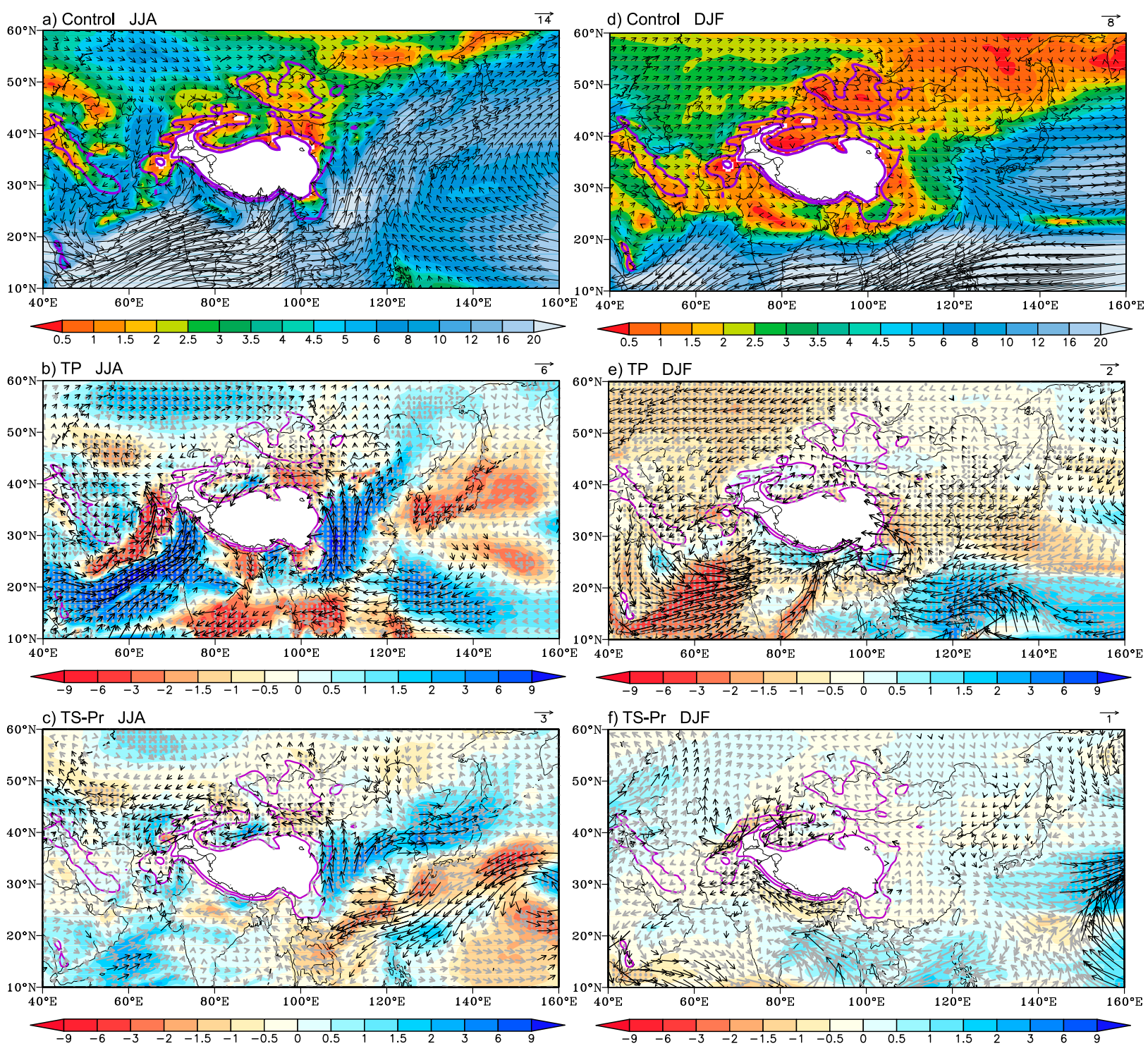

FIG. 9. Change in water vapor transport integrated from the surface to $700 \mathrm{hPa}$ [vectors; $100 \mathrm{~kg} \mathrm{(m} \mathrm{s})^{-1}$ ] and its absolute value [shaded; $100 \mathrm{~kg}\left(\mathrm{~m} \mathrm{~s}^{-1}\right.$ ] in summer and winter: (a) summer mean in the Control run, (b) anomaly induced by the Tibetan Plateau in summer, and (c) anomaly induced by the Tian Shan Mountains and Pamir Plateau in summer. (d)-(f) As in (a)-(c), respectively, but for the mean state and anomaly in winter. The vectors in black and dotted areas indicate where the difference was significant at the $95 \%$ confidence level. The purple contours show the altitude lines of 1500 and $3000 \mathrm{~m}$.

more rains took place as wet southerly winds and ascending motion appeared. With the uplift of the Tibetan Plateau, the summer descending motion below $300 \mathrm{hPa}$ intensified (Fig. 10b). In addition to the strengthened subsidence, a significant divergence anomaly appeared at the latitudes between $35^{\circ}$ and $50^{\circ} \mathrm{N}$ in the lower troposphere and a convergence anomaly occurred in the upper troposphere. Therefore, the meridional circulation anomaly induced by the Tibetan Plateau helped to suppress the summer precipitation of the west arid subregion. The descending motion was also strengthened by the uplift of the Tian Shan Mountains and Pamir Plateau, which was associated with the convergence anomaly in the upper troposphere and the intensified northerly wind in the lower troposphere (Fig. 10c). During winter, a northerly wind anomaly appeared throughout the troposphere with the uplift of the Tibetan Plateau (Fig. 10e). The northerly wind anomaly helped to weaken the southerly transport of moisture to the west arid subregion, resulting in drier conditions in winter. With the Tian Shan Mountains and Pamir Plateau, anomalous divergence circulation occurred throughout the troposphere (Fig. 10f). The 
a) Control JJA

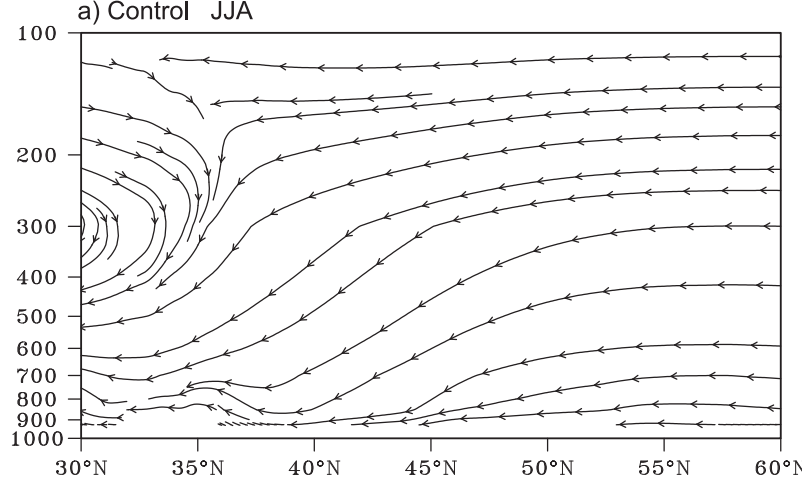

b) TP JJA

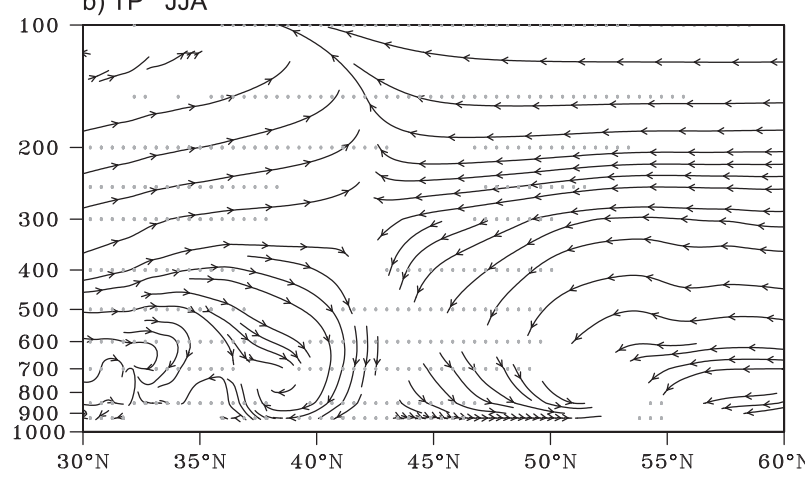

c) TS-Pr JJA

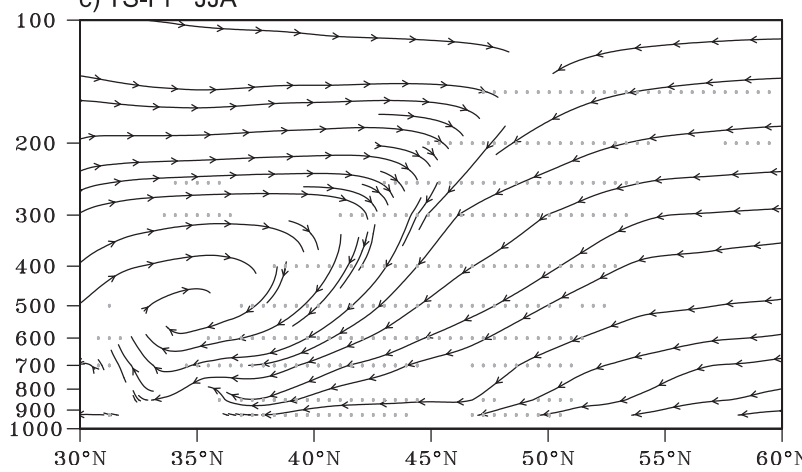

d) Control DJF

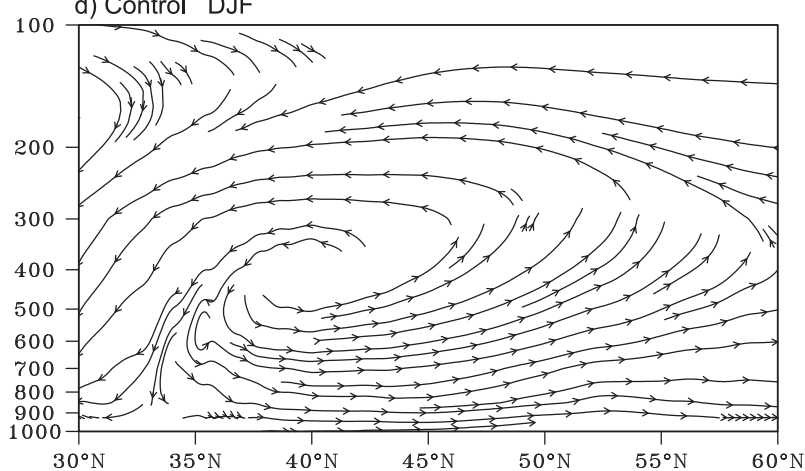

e) TP DJF

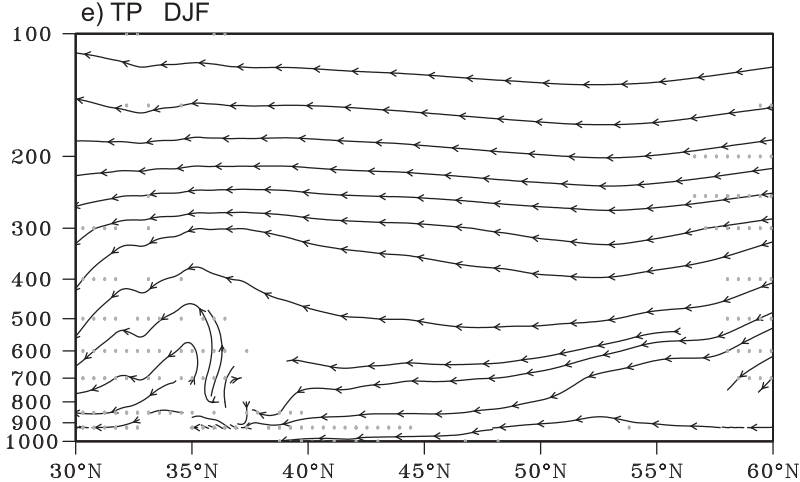

f) TS-Pr DJF

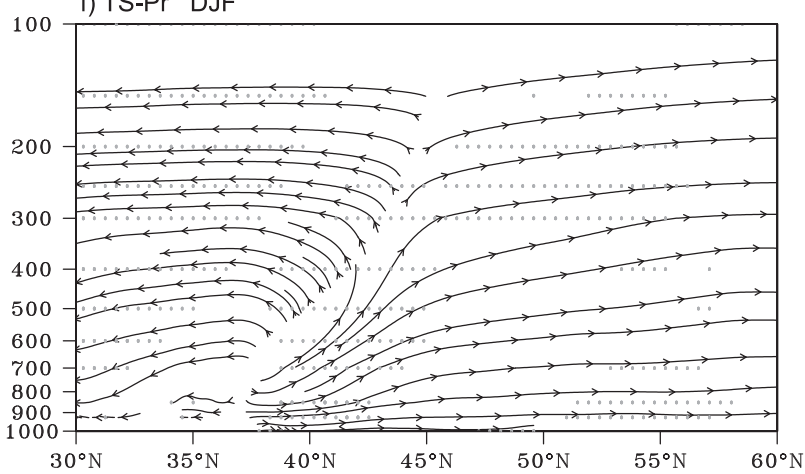

FIG. 10. Latitude-height cross sections of atmospheric circulation (streamlines and vectors; $\mathrm{m} \mathrm{s}^{-1}$ for the meridional wind and $-10^{-3} \mathrm{hPa} \mathrm{s}^{-1}$ for the vertical pressure velocity) averaged between the longitudes of $55^{\circ}$ and $65^{\circ} \mathrm{E}$ in summer and winter: (a) summer mean in the Control run, (b) anomaly induced by the Tibetan Plateau in summer, and (c) anomaly induced by the Tian Shan Mountains and Pamir Plateau in summer. (d)-(f) As in (a)-(c), respectively, but for the mean state and anomaly in winter. The dotted areas indicate where the difference of the wind was significant at the $95 \%$ confidence level.

divergent circulation anomaly would contribute to the precipitation decrease in winter.

Ascending motion appeared over the east arid subregion during summer (Fig. 11a), except the center of the Tarim basin where weak subsidence occurred in the lower troposphere. The lifted air on both the northern slope of the Tibetan Plateau and the Tian Shan Mountains flowed northward and then two local closed circulations were formed; one over the east arid subregion and the other over the north of the Tian Shan Mountains (Fig. 11a). The vertical motion in the east arid subregion changed to distinct subsidence during winter (Fig. 11d). Relative to the meridional circulations in summer (Fig. 11a), the winter circulations at midlatitudes reversed their directions completely (Fig. 11d). The regions between the latitudes of $45^{\circ}$ and $60^{\circ} \mathrm{N}$ were characterized by southerly wind in the lower troposphere, accompanied by ascending motion in winter (Fig. 11d). With the uplift of the Tibetan Plateau, a consistent northerly wind anomaly emerged throughout the whole troposphere in summer (Fig. 11b). 
a) Control JJA
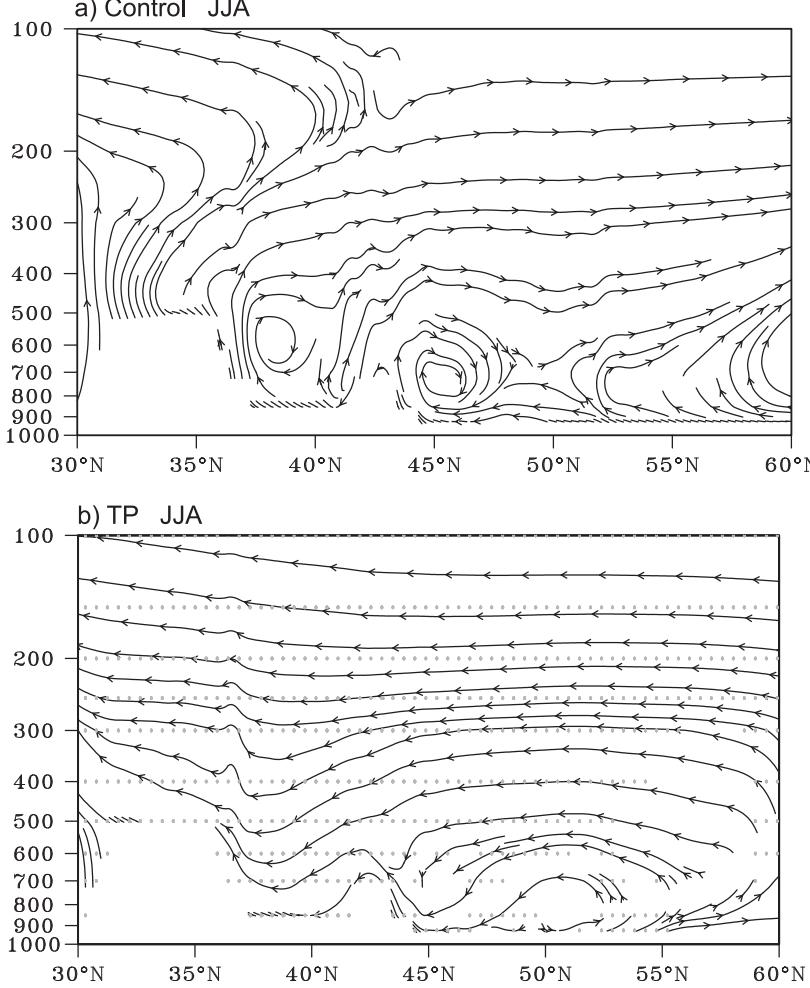

c) TS-Pr JJA

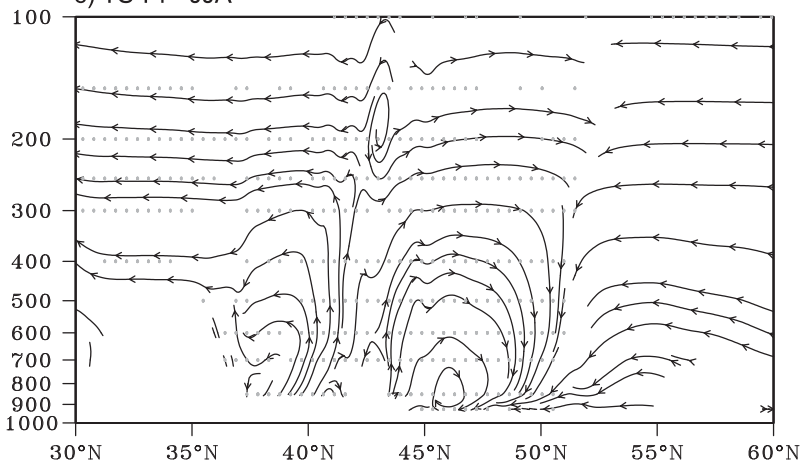

d) Control DJF

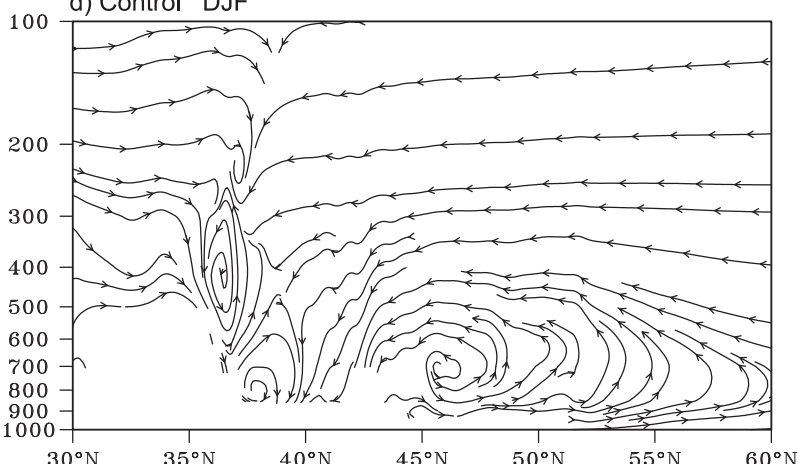

e) TP DJF

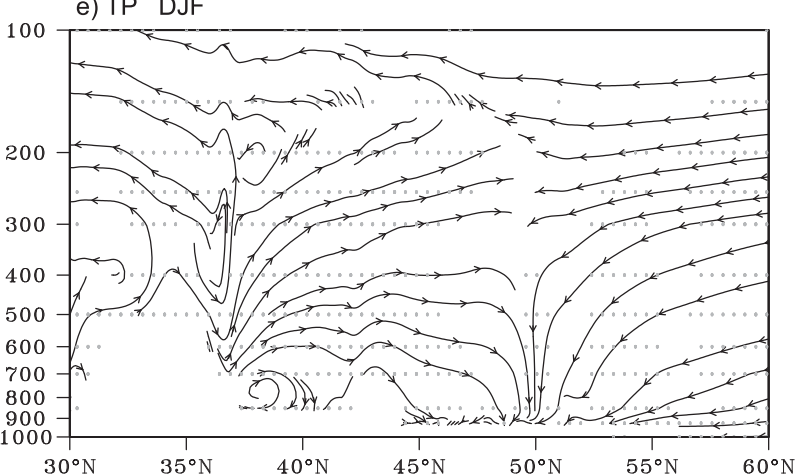

f) TS-Pr DJF

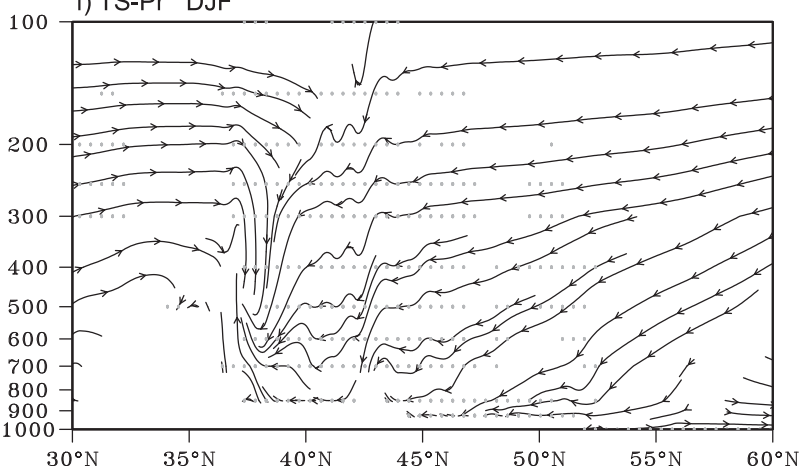

FIG. 11. As in Fig. 10, but for the latitude-height cross sections averaged between the longitudes of $78^{\circ}$ and $88^{\circ} \mathrm{E}$.

A subsidence anomaly appeared over the east arid subregion in summer, which corresponded to the precipitation decrease induced by the Tibetan Plateau. In contrast, the ascending motion in the east arid subregion significantly intensified with the uplift of the Tian Shan Mountains and Pamir Plateau (Fig. 11c), which contributed to the summer precipitation increase. With the appearance of an ascending motion anomaly on the uplifted Tian Shan Mountains, an anomalous meridional cell formed over the regions north of the Tian Shan Mountains, as the air mass rose on the Tian Shan Mountains and sank at higher latitudes between approximately $47^{\circ}$ and $50^{\circ} \mathrm{N}$. During winter, a northerly wind anomaly appeared in the lower troposphere with the uplift of the Tibetan Plateau
(Fig. 11e). The descending motion in the east arid subregion was correspondingly strengthened. Alongside the northerly wind anomaly, a consistent subsidence anomaly also occurred over the east arid subregion with the uplift of the Tian Shan Mountains and Pamir Plateau (Fig. 11f). The intensification of the subsidence induced by the Tibetan Plateau and the Tian Shan MountainsPamir Plateau both helped to suppress the precipitation in winter.

Figure 12 presents the latitude-height cross section averaged between the longitudes of $73^{\circ}$ and $83^{\circ} \mathrm{E}$. The north subregion was under the influence of a closed meridional cell in summer (Fig. 12a). The air mass was lifted on the north slope of the Tian Shan Mountains and 

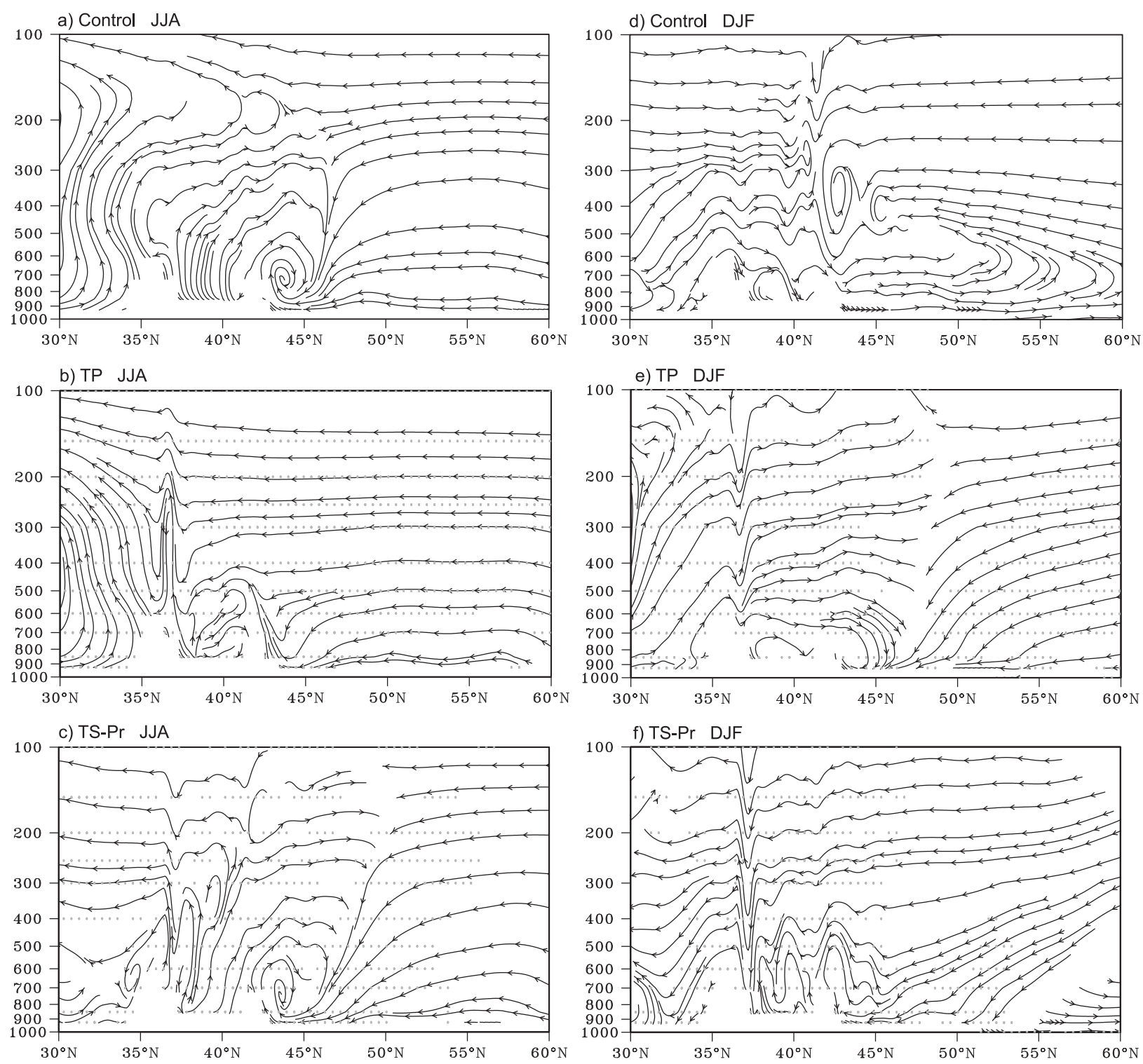

FIG. 12. As in Fig. 10, but for the latitude-height cross sections averaged between the longitudes of $73^{\circ}$ and $83^{\circ} \mathrm{E}$.

then sank at higher latitudes, accompanied by a northerly wind in the lower troposphere and southerly wind in the upper troposphere. During winter, the whole lower and middle troposphere was characterized by southerly wind (Fig. 12d). With the uplift of the Tibetan Plateau, a significant subsidence anomaly occurred both in summer and winter, which suppressed the precipitation intensity (Figs. 12b,e). The whole troposphere was characterized by an anomalous northerly wind in summer. A northerly anomaly also appeared near the surface in winter. With the Tian Shan Mountains and Pamir Plateau, the summer meridional cell was significantly intensified over the north of the Tian Shan Mountains (Fig. 12c). Therefore, a strong subsidence anomaly appeared in the north subregion, with a northerly wind anomaly in the lower troposphere. In contrast to the subsidence anomaly in summer, an anomalous ascending motion occurred with the uplift of the Tian Shan Mountains and Pamir Plateau (Fig. 12f), which was accompanied by more rains in winter.

\section{c. Stationary planetary waves}

Given the essential role of mountain ranges in the modulation of stationary planetary waves, we analyzed the geopotential height anomalies induced by the topography of the Tibetan Plateau and the Tian Shan Mountains and Pamir Plateau (Figs. 13 and 14). The associated temperature anomalies at $500 \mathrm{hPa}$ were also analyzed. With the uplift of the Tibetan Plateau, a positive geopotential 


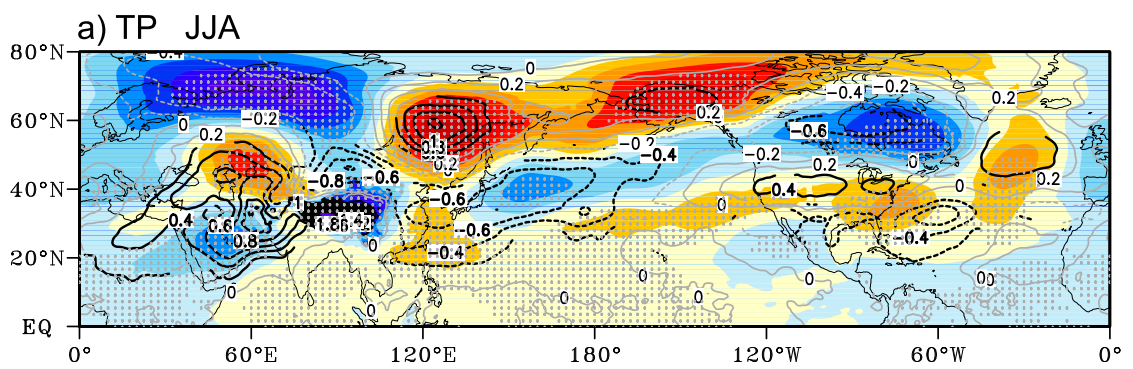

b) TS-Pr JJA

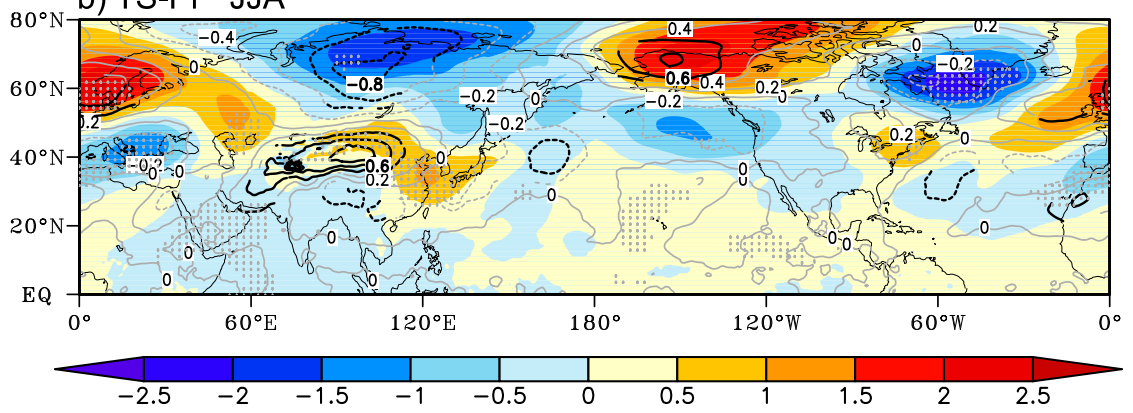

FIG. 13. Change in 500-hPa geopotential height (shaded; $10 \mathrm{~m}$ ) and temperature (contours; ${ }^{\circ} \mathrm{C}$ ) in summer: (a) anomaly induced by the Tibetan Plateau and (b) anomaly induced by the Tian Shan Mountains and Pamir Plateau. The dotted areas and the contours in black indicate where the difference was significant at the $95 \%$ confidence level.

height anomaly occurred over the upwind regions of the Tibetan Plateau in summer, approximately between the latitudes of $40^{\circ}$ and $60^{\circ} \mathrm{N}$ (Fig. 13a). Negative changes emerged on either side of the positive center. One was at higher latitudes above $60^{\circ} \mathrm{N}$ and the other was southwest of the Tibetan Plateau. Significant warming occurred over the entire arid area west of the Tibetan Plateau. Alongside the intense increase in air temperature over the Tibetan Plateau, the 500-hPa geopotential height above the Tibetan Plateau showed a clear decrease in summer, which

a) TP DJF

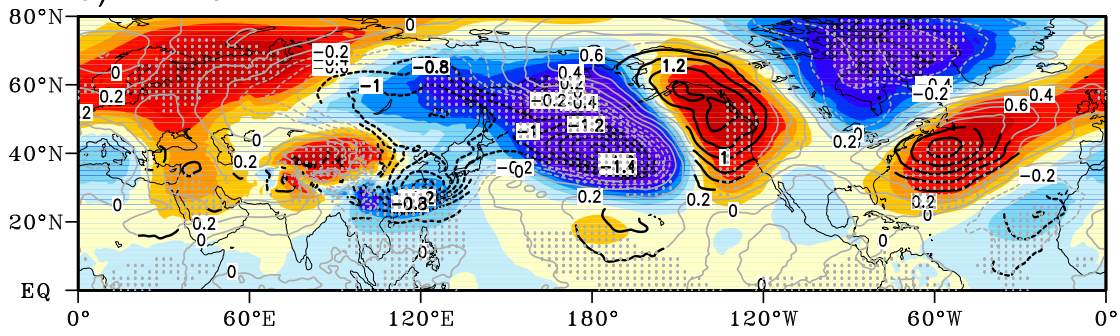

b) TS-Pr DJF
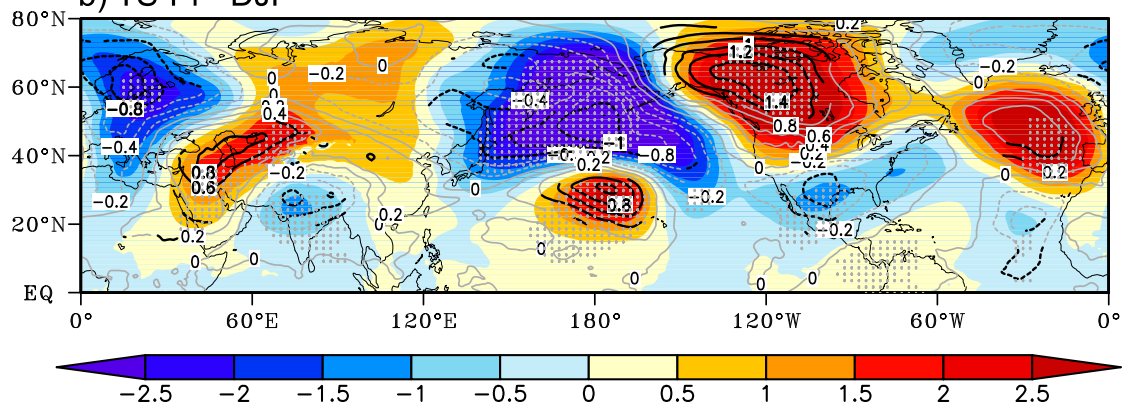

FIG. 14. As in Fig. 13, but for the change in winter. 
was crucial for the inflow and convergence of the air mass toward the Tibetan Plateau. Compared with the meridional negative-positive-negative pattern over the upwind regions of the Tibetan Plateau, the downwind regions were characterized by a positive change in geopotential height, especially in northeastern Eurasia above $40^{\circ} \mathrm{N}$ where air temperature significantly increased. The geopotential height and temperature anomaly propagated farther eastward, and thus a meridional positive-negative-positive pattern also appeared over North America.

With the uplift of the Tian Shan Mountains and Pamir Plateau, a similar negative-positive-negative anomalous change of geopotential height and air temperature occurred (Fig. 13b). The positive center was located between the latitudes of $35^{\circ}$ and $50^{\circ} \mathrm{N}$ and directly above the Tian Shan Mountains, whereas the negative centers were located over the polar and subtropical regions. With the eastward extension of the positive center, East Asia was also under the influence of positive geopotential height. Compared with the modulation induced by the Tibetan Plateau (Fig. 13a), the anomaly induced by the Tian Shan Mountains and Pamir Plateau showed a clearer zonal wave pattern (Fig. 13b), especially the anomaly at higher latitudes, which originated from the negative center north of the Tian Shan Mountains. The different changes in the 500-hPa geopotential height in summer suggest that the modulation of stationary waves induced by the Tian Shan Mountains and Pamir Plateau were extended to higher latitudes, whereas the change induced by the Tibetan Plateau could influence lower latitudes. The difference was related to their relative locations.

Unlike the meridional tripole anomaly of the geopotential height in summer (Fig. 13a), the Tibetan Plateau induced a consistent positive anomaly in the upwind regions during winter (Fig. 14a). Furthermore, a negative anomaly appeared in the downwind region of the Tibetan Plateau, including East Asia and the extratropical west and central Pacific Ocean. This alteration significantly intensified the mean Eurasian ridge and the intense East Asian trough. A positive anomaly and negative anomaly appeared northwest and southeast of the Tibetan Plateau, respectively. The change was a direct response of stationary waves to the Tibetan Plateau, which conforms to the conservation of potential vorticity. The anomalous geopotential height then propagated eastward and strongly influenced North America and the Atlantic Ocean. In addition, the change in $500-\mathrm{hPa}$ temperature in summer induced by the Tibetan Plateau maintained the same sign as that of the geopotential height.

With the uplift of the Tian Shan and Pamir Plateau, a significant positive anomaly of geopotential height and warming appeared in the west and north of the Tian
Shan Mountains-Pamir Plateau and extended to arid subtropical Asia (Fig. 14b). In contrast, an anomalous negative anomaly of potential height and temperature occurred over the Indian Peninsula. This pair of positive and negative anomalies also supported the potential vorticity conservation. The anomaly also propagated as far as the Western Hemisphere, with large amplitude. The anomalous wave pattern induced by the Tian Shan Mountains and Pamir Plateau in winter remained in a relatively northward location compared with that of the Tibetan Plateau (cf. Figs. 14b and 14a). Therefore, accordant higher locations were presented with uplift of the Tian Shan Mountains and Pamir Plateau in both summer and winter. The different meridional locations of the Tibetan Plateau and the Tian Shan MountainsPamir Plateau should be the major cause for the different locations of anomalous stationary waves, regardless of whether the season was winter or summer. In addition to this difference, the two topographies share a similarity that the anomalous wave pattern was located at lower latitudes in winter (Figs. 13b and 14b) than in summer (Figs. 13a and 14a). This common characteristic was related to the meridional movement of westerly wind, as it extends southward in winter and retreats northward in summer.

\section{Summary and discussion}

Numerical experiments were conducted to examine the effect of the Tian Shan Mountains and Pamir Plateau on the aridity in interior Asia, especially the different precipitation seasonality. Before the uplift of the Tian Shan Mountains and Pamir Plateau, arid central Asia west of the mountain ranges and the arid east including northwestern China and southern Mongolia were not separated into the isolated subregions. Instead, the two arid subregions were geographically conjoined as one large arid region. More importantly, the precipitation seasonality in the east arid subregion was completely opposite to the modern summer-peak pattern, with maximum precipitation occurring in winter and spring and the minimum occurring in summer, consistent with that in the west arid subregion. With the uplift of the Tian Shan Mountains and Pamir Plateau, the annual precipitation in the arid west and east subregions both reduced, but it was significantly intensified over the uplifted ranges. The seasonal cycle of precipitation in the east arid subregion switched from the previous winter and spring maximum to the summer maximum, but the precipitation seasonality over the west arid subregion stayed the same. Correspondingly, the differentiation of the precipitation seasonality between the arid west and east subregions was formed. The 
Tian Shan Mountains and Pamir Plateau induced significant transition of precipitation seasonality in the east arid subregions, resulting from the precipitation increase in summer and decrease in winter and spring. In contrast, the west arid subregion was characterized by a slight precipitation decrease in summer and an increase in spring and winter, resulting in intensified precipitation seasonality. The different alteration of precipitation seasonality between the two arid subregions was consistent with the accompanying change in vertical motion. For the east arid subregion, the Tian Shan Mountains and Pamir Plateau induced anomalous ascending motion in summer and descending motion in winter. For the west arid subregion, the anomalous ascending motion in winter and descending motion in summer also corresponded to the seasonal precipitation increase and decrease, respectively.

The precipitation seasonality over the north subregion also changed with the uplift of the Tian Shan Mountains and Pamir Plateau. In the present day, the north subregion receives maximum rainfall in spring and autumn but lowest rainfall in summer. Our experiments show that summer were not be the season with lowest precipitation before the uplift of the Tian Shan and Pamir Plateau. The uplift of the Tian Shan Mountains and Pamir Plateau induced a significant increase in precipitation in spring, autumn, and winter, but a decrease in summer. The numerical simulations support the results of Caves et al. (2017), which were revealed from $\delta^{18} \mathrm{O}$ of pedogenic carbonate deposition. They indicated a $\delta^{18} \mathrm{O}$ decrease over eastern Kazakhstan in the late Neogene was induced by the establishment of modern precipitation seasonality, and further suggested the dominance of spring and autumn precipitation was related to the uplift of the Tian Shan and Altai mountains.

Baldwin and Vecchi (2016) showed that the summer increase in the precipitation induced by the Tian Shan Mountains over the east arid subregion was related to the remote enhancement of the East Asian summer monsoon. Their result showed a consistent increase in summer precipitation and southerly wind over East Asia. Our simulation also revealed an intensified southerly wind over East Asia in summer, but an anomalous anticyclonic circulation localized along the east coast of China. Thus, monsoon precipitation was significantly reduced over eastern China and the subtropical western Pacific Ocean. Nonetheless, a dominant easterly wind also occurred in the east arid subregion during summer, which resembles the wind pattern of the East Asian summer monsoon. The climatological mean moisture flux and 850-hPa horizontal winds of the observations and the Control run both showed that the easterly and southerly wind brought by the East Asian summer monsoon could not reach beyond the regions west of $100^{\circ} \mathrm{E}$. The midlatitude westerlies, after successively flowing along the lower altitudes between the Tian Shan Mountains and the Mongolian Plateau, could intrude as far as the regions in the northeast of the Tibetan Plateau and continue moving eastward. Therefore, the strengthening of the climatological easterly wind in the east arid subregion induced by the Tian Shan Mountains and Pamir Plateau was not associated with the sequential easterly wind that flowed from East Asia.

Based on the conservation of potential vorticity, the uplifted topography produces either horizontal deflection or vertical deflection, or a combination of the two, and forces the modulation of stationary waves (Valdes and Hoskins 1991; Brayshaw et al. 2009; White et al. 2017). Therefore, the Tian Shan Mountains and Pamir Plateau-induced decrease of precipitation over the East Asian summer monsoon-controlled region was closely related to the associated adjustment of stationary waves. In direct contrast with the effect of the Tian Shan Mountains and Pamir Plateau, the East Asian summer monsoon was significantly strengthened with the uplift of the Tibetan Plateau (Kutzbach et al. 1993; An et al. 2001; Liu and Yin 2002; Molnar et al. 2010). By conducting a series of idealized numerical simulations, White et al. (2017) showed that the stationary waves are highly sensitive to the latitude of large-scale topography. Therefore, the different responses of the East Asian summer monsoon to the Tibetan Plateau and the Tian Shan Mountains and Pamir Plateau are related to their different latitudes.

Besides the different locations of the topographies, the location and intensity of the midlatitude westerlies also vary among different seasons. Consequently, the influence of the Tian Shan Mountains and Pamir Plateau on the East Asian summer monsoon was more significant than on the East Asian winter monsoon. In contrast, the Mongolian Plateau significantly intensified the East Asian winter monsoon but had a weak influence on the Asian summer monsoon (Sha et al. 2015). This was also different than the effect of the Tibetan Plateau, as the East Asian summer and winter monsoons were both strengthened. The different responses of the East Asian summer and winter monsoons to the Tian Shan Mountains and Pamir Plateau, the Mongolian Plateau, and the Tibetan Plateau suggest the different interactions of the seasonal midlatitude westerlies with these topographies.

The Tian Shan Mountains and Pamir Plateau played a crucial role in the differentiation of the precipitation seasonality over interior Asia. In addition to the regional changes, the remote East Asian summer monsoon was also modulated, suggesting a nonnegligible influence of relatively small topographies. However, the results of Baldwin and Vecchi (2016), Sato (2005), and 
ours are different in some respects. Our results show a decrease of precipitation in the west subregion but an increase in the east subregion during summer, which is consistent with the results of Baldwin and Vecchi (2016) but different than the results of Sato (2005). In addition, the precipitation of the East Asian summer monsoon shows opposite responses between our results and that of Baldwin and Vecchi (2016). These differences are partly related to the different horizontal resolutions of the models and the different modification of topographies the authors made. Because of the relatively high elevation of the Tarim basin, we only flattened the elevation of the Tian Shan Mountains and the Pamir Plateau to $1200 \mathrm{~m}$. Thus, the elevation of the east arid subregion was kept unaltered to avoid faked climate changes. Therefore, the high resolution of the model we used and the modification of the topography worked fairly well for the scientific question we tried to figure out. We believe that our results are appropriate and reasonable. The different results also suggest that climate is very sensitive to the change of topography, even on a relatively small scale. We should be cautious about the modification of the small topography. More robust results should be provided in further studies using different climate models, but these models must have nearly the same horizontal resolutions and modification of topography.

Acknowledgments. The authors thank the three anonymous reviewers for their careful and thoughtful suggestions that have helped improve the manuscript substantially. The daily gridded precipitation dataset of the APHRODITE project was provided by the Research Institute for Humanity and Nature (RIHN) and the Meteorological Research Institute of Japan Meteorological Agency (MRI/JMA), Japan, and is available at http://www.chikyu.ac.jp/precip/english/products.html. This work is jointly supported by the Strategic Priority Research Program of Chinese Academy of Sciences (XDA20070103), the National Key Research and Development Program of China (2016YFE0109500), the National Natural Science Foundation of China (41572160), and the Chinese Academy of Sciences (QYZDY-SSWDQC001 and ZDBS-SSW-DQC001). Z. Shi acknowledged the Youth Innovation Promotion Association CAS and the Innovative Talents Promotion Plan of Shaanxi (2017KJXX-51).

\section{REFERENCES}

Aizen, E. M., V. B. Aizen, J. M. Melack, T. Nakamura, and T. Ohta, 2001: Precipitation and atmospheric circulation patterns at mid-latitudes of Asia. Int. J. Climatol., 21, 535-556, https:// doi.org/10.1002/joc.626.
An, Z. S., G. Kukla, S. C. Porter, and J. L. Xiao, 1991: Late Quaternary dust flow on the Chinese Loess Plateau. Catena, 18, 125-132, https://doi.org/10.1016/0341-8162(91)90012-M.

_ J. E. Kutzbach, W. L. Prell, and S. C. Porter, 2001: Evolution of Asian monsoons and phased uplift of the HimalayaTibetan plateau since Late Miocene times. Nature, 411, 62 66, https://doi.org/10.1038/35075035.

- , and Coauthors, 2006: Changes of the monsoon-arid environment in China and growth of the Tibetan Plateau since the Miocene (in Chinese). Quat. Sci., 26, 678-693.

Bacmeister, J. T., M. F. Wehner, R. B. Neale, A. Gettelman, C. Hannay, P. H. Lauritzen, J. M. Caron, and J. E. Turesdale, 2014: Exploratory high-resolution climate simulations using the Community Atmosphere Model (CAM). J. Climate, 27, 3073-3099, https://doi.org/10.1175/JCLI-D-13-00387.1.

Baldwin, J., and G. Vecchi, 2016: Influence of the Tian Shan on arid extratropical Asia. J. Climate, 29, 5741-5762, https://doi.org/ 10.1175/JCLI-D-15-0490.1.

Bothe, O., K. Fraedrich, and X. Zhu, 2012: Precipitation climate of Central Asia and the large-scale atmospheric circulation. Theor. Appl. Climatol., 108, 345-354, https://doi.org/10.1007/ s00704-011-0537-2.

Brayshaw, D. J., B. Hoskins, and M. Blackburn, 2009: The basic ingredients of the North Atlantic storm track. Part I: Land-sea contrast and orography. J. Atmos. Sci., 66, 2539-2558, https:// doi.org/10.1175/2009JAS3078.1.

Broccoli, A. J., and S. Manabe, 1992: The effects of orography on midlatitude Northern Hemisphere dry climates. J. Climate, $\mathbf{5}$, 1181-1201, https://doi.org/10.1175/1520-0442(1992)005<1181: TEOOOM $>2.0 . \mathrm{CO} ; 2$.

Caves, J. K., M. J. Winnick, S. A. Graham, D. J. Sjostrom, A. Mulch, and C. P. Chamberlain, 2015: Role of the westerlies in Central Asia climate over the Cenozoic. Earth Planet. Sci. Lett., 428, 33-43, https://doi.org/10.1016/j.epsl.2015.07.023.

_ , and Coauthors, 2017: Late Miocene uplift of the Tian Shan and Altai and reorganization of Central Asia climate. GSA Today, 27, 19-26, https://doi.org/10.1130/GSATG305A.1.

Chang, H., Z. S. An, W. G. Liu, X. K. Qiang, Y. G. Song, and H. Ao, 2012: Magnetostratigraphic and paleoenvironmental records for a late Cenozoic sedimentary sequence drilled from Lop Nor in the eastern Tarim basin. Global Planet. Change, 80-81, 113-122, https://doi.org/10.1016/j.gloplacha.2011.09.008.

Charreau, J., and Coauthors, 2009: Neogene uplift of the Tian Shan Mountains observed in the magnetic record of the Jingou River section (northwest China). Tectonics, 28, TC2008, https://doi.org/10.1029/2007TC002137.

Chen, F. H., and Coauthors, 2010: Moisture changes over the last millennium in arid Central Asia: A review, synthesis and comparison with monsoon region. Quat. Sci. Rev., 29, 10551068, https://doi.org/10.1016/j.quascirev.2010.01.005.

De Grave, J., M. M. Buslov, and P. Van den haute, 2007: Distant effects of India-Eurasia convergence and Mesozoic intracontinental deformation in Central Asia: Constraints from apatite fission-track thermochronology. J. Asian Earth Sci., 29, 188-204, https://doi.org/10.1016/j.jseaes.2006.03.001.

Ding, Z. L., S. F. Xiong, J. M. Sun, S. L. Yang, Z. Y. Gu, and T. S. Liu, 1999: Pedostratigraphy and paleomagnetism of a $\sim 7.0 \mathrm{Ma}$ eolian loess-red clay sequence at Lingtai, Loess Plateau, north-central China and the implications for paleomonsoon evolution. Palaeogeogr. Palaeoclimatol. Palaeoecol., 152, 4966, https://doi.org/10.1016/S0031-0182(99)00034-6.

Dirmeyer, P. A., and K. L. Brubaker, 2007: Characterization of the global hydrologic cycle from a back-trajectory analysis of 
atmospheric water vapor. J. Hydrometeor., 8, 20-37, https:// doi.org/10.1175/JHM557.1.

Guo, Z. T., and Coauthors, 2002: Onset of Asian desertification by $22 \mathrm{Myr}$ ago inferred from loess deposits in China. Nature, 416, 159-163, https://doi.org/10.1038/416159a.

_ - and Coauthors, 2008: A major reorganization of Asian climate by the early Miocene. Climate Past, 4, 153-174, https:// doi.org/10.5194/cp-4-153-2008.

Huang, R. H., and J. L. Chen, 2010: Characteristics of the summertime water vapor transports over the eastern part of China and those over the western part of China and their difference (in Chinese). Chin. J. Atmos. Sci., 34, 1035-1045.

Huang, W., F. H. Chen, S. Feng, J. H. Chen, and X. J. Zhang, 2013: Interannual precipitation variations in the mid-latitude Asia and their association with large-scale atmospheric circulation. Chin. Sci. Bull., 58, 3962-3968, https://doi.org/10.1007/ s11434-013-5970-4.

Kutzbach, J. E., P. J. Guetter, W. F. Ruddiman, and W. L. Prell, 1989: Sensitivity of climate to late Cenozoic uplift in southern Asia and the American West: Numerical experiments. J. Geophys. Res., 94, 18393-18 407, https://doi.org/10.1029/ JD094iD15p18393.

— W. L. Prell, and W. F. Ruddiman, 1993: Sensitivity of Eurasian climate to surface uplift of the Tibetan Plateau. J. Geol., 101, 177-190, https://doi.org/10.1086/648215.

Lioubimtseva, E., R. Cole, J. M. Adams, and G. Kapustin, 2005: Impacts of climate and land-cover changes in arid lands of Central Asia. J. Arid Environ., 62, 285-308, https://doi.org/ 10.1016/j.jaridenv.2004.11.005.

Liu, T. S., 1985: Loess and the Environment. China Ocean Press, $251 \mathrm{pp}$.

Liu, W. G., Z. H. Liu, Z. S. An, J. M. Sun, H. Chang, N. Wang, J. B. Dong, and H. Y. Wang, 2014: Late Miocene episodic lakes in the arid Tarim basin, western China. Proc. Natl. Acad. Sci. USA, 111, 16 292-16296, https://doi.org/10.1073/pnas.1410890111.

Liu, X. D., and Z.-Y. Yin, 2002: Sensitivity of East Asian monsoon climate to the uplift of the Tibetan Plateau. Palaeogeogr. Palaeoclimatol. Palaeoecol., 183, 223-245, https://doi.org/ 10.1016/S0031-0182(01)00488-6.

_ , and B. W. Dong, 2013: Influence of the Tibetan Plateau uplift on the Asian monsoon-arid environment evolution. Chin. Sci. Bull., 58, 4277-4291, https://doi.org/10.1007/s11434-013-5987-8.

- , H. Sun, Y. F. Miao, B. W. Dong, and Z.-Y. Yin, 2015: Impacts of uplift of northern Tibetan Plateau and formation of Asian inland deserts on regional climate and environment. Quat. Sci. Rev., 116, 1-14, https://doi.org/10.1016/j.quascirev.2015.03.010.

Martyn, D., 1992: Climates of the World. Elsevier, 435 pp.

Molnar, P., W. R. Boos, and D. S. Battisti, 2010: Orographic controls on climate and paleoclimate of Asia: Thermal and mechanical roles for the Tibetan Plateau. Annu. Rev. Earth Planet. Sci., 38, 77-102, https://doi.org/10.1146/annurev-earth-040809-152456.

Neale, R. B., and Coauthors, 2010: Description of the NCAR Community Atmosphere Model (CAM 4.0). NCAR Tech. Note NCAR/TN-485+ STR, 212 pp., www.cesm.ucar.edu/ models/ccsm4.0/cam/docs/description/cam4_desc.pdf.

Qiang, X. K., and Coauthors, 2011: New eolian red clay sequence on the western Chinese Loess Plateau linked to onset of Asian desertification about 25 Ma ago. Sci. China Earth Sci., 54, 136-144, https://doi.org/10.1007/s11430-010-4126-5.

Rea, D. K., H. Snoeckx, and L. H. Joseph, 1998: Late Cenozoic eolian deposition in the North Pacific: Asian drying, Tibetan uplift, and cooling of the Northern Hemisphere. Paleoceanography, 13, 215-224, https://doi.org/10.1029/98PA00123.
Rowley, D. B., and B. S. Currie, 2006: Palaeo-altimetry of the late Eocene to Miocene Lunpola basin, central Tibet. Nature, 439, 677-681, https://doi.org/10.1038/nature04506.

Sato, T., 2005: The TianShan rain-shadow influence on the arid climate formation in northwestern China. SOLA, 1, 13-16, https://doi.org/10.2151/sola.2005-004.

_ 2009: Influences of subtropical jet and Tibetan Plateau on precipitation pattern in Asia: Insights from regional climate modeling. Quat. Int., 194, 148-158, https://doi.org/10.1016/j. quaint.2008.07.008.

, and Coauthors, 2007: Water sources in semiarid northeast Asia as revealed by field observations and isotope transport model. J. Geophys. Res., 112, D17112, https://doi.org/10.1029/ 2006JD008321.

Schiemann, R., D. Lüthi, P. L. Vidale, and C. Schär, 2008: The precipitation climate of Central Asia-Intercomparison of observational and numerical data sources in a remote semiarid region. Int. J. Climatol., 28, 295-314, https://doi.org/10.1002/joc.1532.

Sha, Y. Y., Z. G. Shi, X. D. Liu, and Z. S. An, 2015: Distinct impacts of the Mongolian and Tibetan Plateaus on the evolution of the East Asian monsoon. J. Geophys. Res. Atmos., 120, 4764-4782, https://doi.org/10.1002/2014JD022880.

Shi, Z. G., X. D. Liu, Z. S. An, B. Q. Yi, P. Yang, and N. Mahowald, 2011: Simulated variations of eolian dust from inner Asian deserts at the mid-Pliocene, Last Glacial Maximum, and present day: Contributions from the regional tectonic uplift and global climate change. Climate Dyn., 37, 2289-2301, https://doi.org/10.1007/s00382-011-1078-1.

,-- Y. M. Liu, Y. Y. Sha, and T. T. Xu, 2015: Impact of Mongolian Plateau versus Tibetan Plateau on the westerly jet over North Pacific Ocean. Climate Dyn., 44, 3067-3076, https://doi.org/10.1007/s00382-014-2217-2.

, Y. Y. Sha, and X. D. Liu, 2017: Effect of Yunnan-Guizhou topography at the southeastern Tibetan Plateau on the Indian monsoon. J. Climate, 30, 1259-1272, https://doi.org/10.1175/ JCLI-D-16-0105.1.

Sobel, E. R., L. M. Schoenbohm, J. Chen, R. Thiede, D. F. Stockli, M. Sudo, and M. R. Strecker, 2011: Late Miocene-Pliocene deceleration of dextral slip between Pamir and Tarim: Implications for Pamir orogenesis. Earth Planet. Sci. Lett., 304, 369378, https://doi.org/10.1016/j.epsl.2011.02.012.

Sun, J. M., R. X. Zhu, and J. Bowler, 2004: Timing of the Tianshan Mountains uplift constrained by magnetostratigraphic analysis of molasse deposits. Earth Planet. Sci. Lett., 219, 239-253, https://doi.org/10.1016/S0012-821X(04)00008-1.

— J. Ye, W. Y. Wu, X. J. Ni, S. D. Bi, Z. Q. Zhang, W. M. Liu, and J. Meng, 2010: Late Oligocene-Miocene mid-latitude aridification and wind patterns in the Asian interior. Geology, 38, 515-518, https://doi.org/10.1130/G30776.1.

, Z. J. Gong, Z. H. Tian, Y. Y. Jia, and B. Windley, 2015: Late Miocene stepwise aridification in the Asian interior and the interplay between tectonics and climate. Palaeogeogr. Palaeoclimatol. Palaeoecol., 421, 48-59, https://doi.org/10.1016/ j.palaeo.2015.01.001.

Syed, F. S., F. Giorgi, J. S. Pal, and M. P. King, 2006: Effect of remote forcings on the winter precipitation of central southwest Asia. Part 1: Observations. Theor. Appl. Climatol., 86, 147-160, https://doi.org/10.1007/s00704-005-0217-1.

Tian, L., V. Masson-Delmotte, M. Stievenard, T. Yao, and J. Jouzel, 2001: Tibetan Plateau summer monsoon northward extent revealed by measurements of water stable isotopes. J. Geophys. Res., 106, 28 081-28 088, https://doi.org/10.1029/ 2001JD900186. 
Valdes, P. J., and B. J. Hoskins, 1991: Nonlinear orographically forced planetary waves. J. Atmos. Sci., 48, 2089-2106, https://doi.org/ 10.1175/1520-0469(1991)048<2089:NOFPW>2.0.CO;2.

White, R. H., D. S. Battisti, and G. H. Roe, 2017: Mongolian mountains matter most: Impacts of the latitude and height of Asian orography on Pacific wintertime atmospheric circulation. J. Climate, 30, 4065-4082, https://doi.org/10.1175/ JCLI-D-16-0401.1.

Wu, G. X., and Coauthors, 2007: The influence of mechanical and thermal forcing by the Tibetan Plateau on Asian climate. J. Hydrometeor., 8, 770-789, https://doi.org/10.1175/ JHM609.1.

Yanai, M., and C. F. Li, 1994: Mechanism of heating and the boundary layer over the Tibetan Plateau. Mon. Wea. Rev., 122, 305-323, https://doi.org/10.1175/1520-0493(1994)122<0305: MOHATB $>2.0 . \mathrm{CO} ; 2$.

Yatagai, A., and T. Yasunari, 1998: Variation of summer water vapor transport related to precipitation over and around the arid region in the interior of the Eurasian continent. J. Meteor. Soc. Japan, 76, 799-815, https://doi.org/10.2151/ jmsj1965.76.5_799.

, T. N. Krishnamurti, V. Kumar, A. K. Mishra, and A. Simon, 2014: Use of APHRODITE rain gauge-based precipitation and TRMM 3B43 products for improving Asian monsoon seasonal precipitation forecasts by the superensemble method. J. Climate, 27, 1062-1069, https://doi.org/10.1175/JCLI-D-13-00332.1.
Ye, D. Z., and Y. X. Gao, 1979: Meteorology of the Qinghai-Xizang Plateau. Chinese Science Press, 278 pp.

Yin, Z.-Y., H. L. Wang, and X. D. Liu, 2014: A comparative study on precipitation climatology and interannual variability in the lower midlatitude East Asia and Central central Asia. J. Climate, 27, 7830-7848, https://doi.org/10.1175/JCLI-D-14-00052.1.

Yu, G., S. P. Harrison, and B. Xue, 2001: Lake status records from China: Data base documentation. Max-Planck-Institute fur Biogeochemie Tech. Rep. 4, 50 pp.

Zhang, G. J., and N. A. McFarlane, 1995: Sensitivity of climate simulations to the parameterization of cumulus convection in the $\mathrm{Ca}$ nadian Climate Centre general circulation model. Atmos.-Ocean, 33, 407-446, https://doi.org/10.1080/07055900.1995.9649539.

Zhang, R., D. B. Jiang, Z. S. Zhang, and E. T. Yu, 2015: The impact of regional uplift of the Tibetan Plateau on the Asian monsoon climate. Palaeogeogr. Palaeoclimatol. Palaeoecol., 417, 137150, https://doi.org/10.1016/j.palaeo.2014.10.030.

Zheng, H. B., C. M. Powell, Z. S. An, J. Zhou, and G. R. Dong, 2000: Pliocene uplift of the northern Tibetan Plateau. Geology, 28, 715-718, https://doi.org/10.1130/0091-7613(2000)28<715: PUOTNT $>2.0 . \mathrm{CO} ; 2$.

Zhu, X. F., M. J. Zhang, S. J. Wang, F. Qiang, T. Zeng, Z. G. Ren, and L. Dong, 2015: Comparison of monthly precipitation derived from high-resolution gridded datasets in arid Xinjiang, Central Asia. Quat. Int., 358, 160-170, https://doi.org/10.1016/ j.quaint.2014.12.027. 